\title{
Unsustainable Imbalances and Inequities in Carbon-Water-Energy Flows across the EU27
}

\author{
Xue-Chao Wang ${ }^{1, *}$, Jiří Jaromír Klemeš ${ }^{1}$, Yutao Wang ${ }^{2}$, Aoife Foley ${ }^{3,4}$, Donald Huisingh ${ }^{5}$, \\ Dabo Guan $^{6,7}$, Xiaobin Dong ${ }^{8}$, Petar Sabev Varbanov ${ }^{1}$ \\ ${ }^{1}$ Sustainable Process Integration Laboratory - SPIL, NETME Centre, Faculty of Mechanical Engineering, Brno \\ University of Technology - VUT Brno, Technická 2896/2, 61669 Brno, Czech Republic \\ ${ }^{2}$ Fudan Tyndall Center and Shanghai Key Laboratory of Atmospheric Particle Pollution and Prevention (LAP3), \\ Department of Environmental Science \& Engineering, Fudan University, Shanghai 200438, China \\ ${ }^{3}$ School of Mechanical and Aerospace Engineering, Queen's University Belfast, Belfast BT9 5AH, United \\ Kingdom. \\ ${ }^{4}$ Department of Civil, Structural \& Environmental Engineering, Trinity College Dublin, University of Dublin, \\ Dublin D02 PN40, Ireland. \\ ${ }^{5}$ The Institute for a Secure and Sustainable Environment, The University of Tennessee, Knoxville, Tennessee \\ 37996, USA \\ ${ }^{6}$ Department of Earth System Sciences, Tsinghua University, Beijing 100080, China \\ ${ }^{7}$ The Bartlett School of Construction and Project Management, University College London, London WC1E 6BT, \\ United Kingdom \\ ${ }^{8}$ State Key Laboratory of Earth Surface Processes and Resource Ecology, Faculty of Geographical Science, Beijing \\ Normal University, Beijing 100875, China \\ Corresponding author: Xue-Chao Wang, wang@fme.vutbr.cz
}

\begin{abstract}
The EU27 countries exert significant influence on the global patterns of the $\mathrm{CO}_{2}$-EmissionsWater-Energy (CWE) nexus. However, whether the associated benefits are similar for all countries is unclear. The authors of this paper constructed an EU27, multiregional input-output model, at a sector level to identify the inter-regional and -sectoral CWE flows, and clarify the regional, sectoral and worldwide patterns of EU27 CWE network. The results revealed an environmental inequality across the EU27 and impacts on the rest of the world. The EU27 countries contributed $1.4 \mathrm{Gt}$ less $\mathrm{CO}_{2}$ emissions, $64.5 \mathrm{Gm}^{3}$ less water utilisation and $49 \mathrm{EJ}$ less energy consumption, compared to the rest of the world while generating the equivalent economic output in 2014. This has dramatic effects upon the global environment. Germany, France and Italy are the biggest beneficiaries in the CWE nexus in the EU27. The authors recommended that the EU27 provide more technical support to upstream countries in the EU and elsewhere to strive to improve their resource utilisation efficiencies.
\end{abstract}

\section{Keywords}

Carbon-Water-Energy Flows, Embodied Energy, Embodied $\mathrm{CO}_{2}$; Embodied Water, EU27; Input-Output Model; 


\section{Nomenclature}

\begin{tabular}{|c|c|c|}
\hline Symbol & Meaning & Unit \\
\hline$z_{i, j}^{r, s}$ & $\begin{array}{l}\text { Inter-sectoral monetary flow from sector } i \text { in economy } r \text { to sector } \\
j \text { in economy } s\end{array}$ & $€$ \\
\hline$f_{i, k}^{r, s}$ & $\begin{array}{l}\text { Final demand of term } k \text { in the economy } s \text { from sector } i \text { in economy } \\
r\end{array}$ & $€$ \\
\hline$x_{i}^{r}$ & Total output of sector $i$ in economy $r$ & $€$ \\
\hline$v_{j}^{S}$ & Added value of sector $j$ in economy $s$ & $€$ \\
\hline$x_{j}^{S}$ & Total input of sector $j$ in economy $s$ & $€$ \\
\hline$e_{j}^{S}$ & Direct energy input of sector $j$ in economy $s$ & $\mathrm{~J}$ \\
\hline$w_{j}^{S}$ & Direct water input of sector $j$ in economy $s$ & $\mathrm{~m}^{3}$ \\
\hline$c_{j}^{S}$ & Direct $\mathrm{CO}_{2}$ emissions from sector $j$ in economy $s$ & $\mathrm{t}$ \\
\hline$\varepsilon_{j}^{S}$ & Embodied energy intensity of sector $j$ in economy $s$ & $\mathrm{~J} / €$ \\
\hline$z_{j, i}^{r, s}$ & $\begin{array}{l}\text { Intermediate embodied energy, or water, or carbon flow from } \\
\text { sector } j \text { in economy } r \text { to sector } i \text { in economy } s\end{array}$ & $\mathrm{~J} ; \mathrm{m}^{3} ; \mathrm{t}$ \\
\hline$\varepsilon_{i}^{r}$ & Embodied energy intensity of sector $\mathrm{i}$ in economy $\mathrm{r}$ & $\mathrm{J}$ \\
\hline$\omega_{j}^{s}$ & Embodied water intensity of output from sector $j$ in economy $s$ & $\mathrm{~m}^{3} / €$ \\
\hline$\omega_{i}^{r}$ & Embodied water intensity of output from sector $i$ in economy $r$ & $\mathrm{~m}^{3} / €$ \\
\hline$\theta_{j}^{S}$ & $\begin{array}{l}\text { Embodied } \mathrm{CO}_{2} \text { emission intensity of output from sector } j \text { in } \\
\text { economy } s\end{array}$ & $\mathrm{t} / €$ \\
\hline$\theta_{i}^{r}$ & $\begin{array}{l}\text { Embodied } \mathrm{CO}_{2} \text { emission intensity of output from sector } i \text { in } \\
\text { economy } r\end{array}$ & $\mathrm{t} / €$ \\
\hline$I E E_{i}^{r}$ & Import embodied energy consumption of sector $i$ in economy $r$ & $\mathrm{~J}$ \\
\hline$E E E_{i}^{r}$ & Export embodied energy consumption of sector $i$ in economy $r$ & $\mathrm{~J}$ \\
\hline$I E E^{r}$ & Import embodied energy consumption of economy $r$ & $\mathrm{~J}$ \\
\hline$E E E^{r}$ & Export embodied energy consumption of economy $r$ & $\mathrm{~J}$ \\
\hline$D E E^{r}$ & Net value of import and export embodied energy consumption & $\mathrm{J}$ \\
\hline
\end{tabular}




\begin{tabular}{|c|c|c|}
\hline$I W E^{r}$ & Import embodied water consumption of economy $r$ & $\mathrm{~m}^{3}$ \\
\hline$E W E^{r}$ & Import embodied water consumption of economy $r$ & $\mathrm{~m}^{3}$ \\
\hline$D W E^{r}$ & Net value of import and export embodied water consumption & $\mathrm{m}^{3}$ \\
\hline$I C E^{r}$ & Import embodied $\mathrm{CO}_{2}$ emission of economy $r$ & $t$ \\
\hline$E C E^{r}$ & Export embodied $\mathrm{CO}_{2}$ emission of economy $r$ & $t$ \\
\hline$D C E^{r}$ & Net value of import and export embodied $\mathrm{CO}_{2}$ emission & $\mathrm{t}$ \\
\hline$A_{E U-C}$ & Average coefficients of embodied $\mathrm{CO}_{2}$ emissions of EU27 & $\mathrm{t} / €$ \\
\hline$A_{E U-W}$ & Average coefficients of embodied water consumption of EU27 & $\mathrm{m}^{3} / €$ \\
\hline$A_{E U-E}$ & Average coefficients of embodied energy consumption of EU27 & $\mathrm{J} / €$ \\
\hline$A_{W O-C}$ & Average coefficients of embodied $\mathrm{CO}_{2}$ emissions of non-EU27 & $\mathrm{t} / €$ \\
\hline$A_{W O-W}$ & Average coefficients of embodied water utilisation of non-EU27 & $\mathrm{m}^{3} / €$ \\
\hline$A_{W O-E}$ & $\begin{array}{l}\text { Average coefficients of embodied energy consumption of non- } \\
\text { EU27 }\end{array}$ & $\mathrm{J} / €$ \\
\hline$D_{C}$ & $\begin{array}{l}\text { The amount of embodied } \mathrm{CO}_{2} \text { emissions that EU } 27 \text { import from } \\
\text { the rest of the world }\end{array}$ & $\mathrm{t}$ \\
\hline$D_{W}$ & $\begin{array}{l}\text { The amount of embodied water that EU } 27 \text { import from the rest of } \\
\text { the world }\end{array}$ & $\mathrm{m}^{3}$ \\
\hline$D_{E}$ & $\begin{array}{l}\text { The amount of embodied energy that EU } 27 \text { import from the rest } \\
\text { of the world }\end{array}$ & $\mathbf{I}$ \\
\hline$R_{C}$ & The reduction amount of embodied $\mathrm{CO}_{2}$ emissions by EU27 & $\mathrm{t}$ \\
\hline$R_{W}$ & The reduction amount of embodied water by EU27 & $\mathrm{m}^{3}$ \\
\hline$R_{E}$ & The reduction amount of embodied energy by EU27 & $\mathbf{J}$ \\
\hline
\end{tabular}

\section{Abbreviations/ Acronyms}

\begin{tabular}{ll}
\hline Abbreviations & Full Names \\
\hline GHG & Greenhouse Gases \\
UN & United Nations \\
SDGs & United Nations Sustainable Development Goals \\
UNFCCC & United Nations Framework Convention on Climate Change
\end{tabular}




\begin{tabular}{|c|c|}
\hline $\mathrm{CO}_{2}$ & Carbon Dioxide \\
\hline CWE & $\mathrm{CO}_{2}$ - Water - Energy \\
\hline MRIO & Multi-Regional Input-Output \\
\hline AUT & Austria \\
\hline BEL & Belgium \\
\hline BGR & Bulgaria \\
\hline HRV & Croatia \\
\hline CYP & Cyprus \\
\hline CZE & Czech Republic \\
\hline DNK & Denmark \\
\hline EST & Estonia \\
\hline FIN & Finland \\
\hline LVA & France \\
\hline LTU & Lithuania \\
\hline LUX & Luxembourg \\
\hline MLT & Malta \\
\hline NLD & Netherlands \\
\hline POL & Poland \\
\hline PRT & Portugal \\
\hline $\mathrm{ROU}$ & Romania \\
\hline SVK & Slovakia \\
\hline SVN & Slovenia \\
\hline ESP & Spain \\
\hline SWE & Sweden \\
\hline EIO & Environmental Input-Output \\
\hline WIOD & World Input-Output Database \\
\hline MFA & Material Flow Analysis \\
\hline LCA & Life Cycle Assessment \\
\hline WIOT & World Input-Output Tables \\
\hline GDP & Gross Domestic Product \\
\hline $\mathrm{A} \& \mathrm{~F}$ & Agriculture and Forestry \\
\hline M\&Q & Mining and Quarrying \\
\hline MAN & Manufacturing \\
\hline
\end{tabular}




$\begin{array}{ll}\text { ENE } & \text { Energy Supply } \\ \text { WAT } & \text { Water Management } \\ \text { WAS } & \text { Waste Management } \\ \text { CON } & \text { Construction } \\ \text { W\&R } & \text { Wholesale and Retail Trade } \\ \text { T\&W } & \text { Transport and Warehousing } \\ \text { SOC } & \text { Social Services } \\ \text { NAFTA } & \text { North American Free Trade Agreement } \\ \text { WTO } & \text { World Trade Organization } \\ \text { ASEAN } & \text { Association of South-East Asian Nations }\end{array}$

\section{Introduction}

The EU27 members, as one of the biggest economies, have become increasingly interlinked. Large quantities of raw materials, products and energy are transported among the EU27 countries and throughout the world. A massive amount of embodied materials and energy are shared, which is a significant growth booster for the economy of many countries. However, the question of whether the interests are mutual for all members needs more in-depth analysis, especially when focusing on three of the most basic environmental and economic strategy elements, which are carbon, energy and water. These three impact factors are intensely entwined [1]. Exploring the nexus of carbon emissions, water and energy has important strategic significance for both regional and global sustainability.

\subsection{The Daunting Challenge of Climate Change Remains}

Percapita, global greenhouse gas (GHG) emissions continue to increase in spite of some progress in implementation of the United Nation (UN) Sustainable Development Goals (SDGs) and the Framework Convention on Climate Change (UNFCCC) [2]. At present rates, global warming would result in $1.5^{\circ} \mathrm{C}$ increase compared to the preindustrial levels in 15 to 20 years. If humankind wishes to keep the increase below the $1.5^{\circ} \mathrm{C}$ targets, $\mathrm{GHG}$ emissions have to be reduced to net zero increase within the next 30 to $40 \mathrm{y}$ [3]. The likelihood of achieving the $1.5^{\circ} \mathrm{C}$ targets will be less like a considerably decrease if the measures were postponed to 2030 [4]. To meet the $2{ }^{\circ} \mathrm{C}$ target, a massive volume of fossil fuels should be untapped globally from 2010 to 2050 , including $33 \%$ of oil reserves, $50 \%$ of gas reserves and over $80 \%$ of current coal reserves, which is a daunting and perhaps one of the biggest global challenges humanity will 
ever face [5]. Emissions of $\mathrm{CO}_{2}$, one of the key GHG emissions, accounts for two-thirds of GHG [6]. The top ten $\mathrm{CO}_{2}$ emitters in the world in 2017 were China, the USA, the EU27, India, Russia, Japan, Iran, Sandi Arabia, South Korea, and Canada [7]. The EU27 contributes 8.7\% $(3.12 \mathrm{Gt})$ to global emissions, which is less than the quantity emitted by China (27\%) and the $\operatorname{USA}(15 \%)[7]$.

If the EU27 are considered as separate countries, then Germany (800 Mt) would be positioned after Japan $(1.19 \mathrm{Gt})$. Other EU27 emitters in the top twenty list are France (347 Mt) and Italy (349 Mt) [7]. The primary focus in global climate action and policy has to be on GHG reductions. With the global human population increasing at a net rate of $83,000,000 / y$, they are major challenges and opportunities to develop and implement new policies, procedures and technologies within new normal societies in the post-COVID-19 era [8].

\subsection{Profoundly Entwined Carbon, Energy and Water}

Many measures and targets have been revolving around $\mathrm{CO}_{2}$ emissions, but this is not the complete picture. The real impacts of the UNFCCC and the more recent Paris Agreement [9] still need accurate quantification. The 17 SDGs offer a more comprehensive way to contribute to the global sustainable development, where food, water, and affordable, clean energy within the context of sustainable partnerships are outlined so that a sustainable future becomes a reality for all. Climate changes are already causing significant uncertainties in water resource security and management [10], and trigger negative effects on both energy demands and the resilience of energy systems [11]. If this continues, there will be increases in social disharmony and political imbalance.

Global and regional trade, results in major displacements of social and environmental influences, which accompany the massive embodied flows of energy, water and $\mathrm{CO}_{2}$ emissions [12]. The net $\mathrm{CO}_{2}$ emissions transferred from developing to developed countries significantly increased due to global trade during the past decade [13]. It demonstrates that international trade plays a crucial role in explaining national emissions worldwide. It is important to monitor the embodied materials transfers via regional or global trade, for the stabilisation of global $\mathrm{CO}_{2}$ emissions.

The disparities among countries or regions in embodied $\mathrm{CO}_{2}$ - Water - Energy (CWE) flows still needs to be systematically researched. Previously, fossil fuel security was king in the global energy landscape, but climate changes, increasing human population growth combined with the effects of the global COVID-19 pandemic are causing unprecedented societal changes. 
Globally, total water and energy consumption continue to rise. Energy consumption will continue to increase as well, although with more variability. An important factor in global CWE flows is that the real and virtual footprints for water and energy are very different depending on economic activity [14]. These phenomena were examined considering the SDGs and to highlight the disparities and inequities in the current CWE nexus. In this study, embodied $\mathrm{CO}_{2}$, embodied water and embodied energy were defined as the total $\mathrm{CO}_{2}$ emitted, water used and energy consumed for generating a product or for providing a particular service [15]. They cover the entire process from raw materials to final products from the supply chain and life cycle perspectives.

An urgently needed understanding of the CWE nexus is important for helping societies to more effectively mitigate climate changes [15], improve energy and water resource security [16], upgrade resource efficiency management [17], reduce environmental footprints [18], and promote regional sustainability [19]. Typically, $\mathrm{CO}_{2}$ emissions are considered to be pollution and energy is considered as a paid-for resource [20]. However, 'free' water is mostly studied in isolation and has no real borders. It is also analysed very differently by discipline, expert and country, depending upon the user's needs [21]. Some authors have examined total water and virtual water footprints in isolation by looking at green, blue, and greywater flows [22].

\subsection{Research Importance}

No publication, to date, was designed to examine CWE flows in a holistic approach to address climate changes. The CWE flows across the EU27 countries are explored using a Multiregional Input-Output (MRIO) approach. The $\mathrm{CO}_{2}$, water and energy embodied in interregional trade of products across the EU27 and the rest of the world were analysed. Embodied water was used for measuring the total amount of water involved in producing materials, indicating the sum of all water that is embodied in generating the product or in providing the service itself from the supply chain perspective. It usually involves a set of inter-linked sectors in different regions. The embodied energy and embodied $\mathrm{CO}_{2}$ are defined in the same way. The MRIO flows are divided at a sectoral level to identify trends and strengths, challenges, and weaknesses in the ecosystem. Our findings are discussed in the context of EU27 'Effort Sharing' and binding emissions targets, and energy and water security, considering the SDGs, equity and the environment.

\section{Data}


The EU27 countries, after BREXIT, were taken as cases in this study. However, this study not only focuses on the EU27 members; the linkages between the EU27 countries and the rest of the world are crucial as well. It is important to explore the global patterns of EU27 CWE nexus. Therefore, the authors included the rest of the world as the $28^{\text {th }}$ region. The Multi-Regional Input-Output (MRIO) model has been developed and employed, which was based on the WIOD (World Input-Output Database) [23], and the output of the relevant environmental impacts, which includes the latest year (2014) data of energy consumption and $\mathrm{CO}_{2}$ emissions from different regions/countries that involved in this study [24].

The monetary units in the input-output table were changed from USDs to EURs according to the rate from the World Bank [25]. The following kinds of energy were included in the analyses: Coke, Coal, Gasoline, Electricity, Crude, Naphtha, Jet Fuel, Biodiesel, Light Fuel Oil, Heavy Fuel Oil, other Petrol, Natural Gas, Wind, Geothermal, Diesel, Hydro, Biogas, Solar, Waste and Nuclear. The data of water utilisation were obtained and processed from the Eurostat [26]. The World Bank database was used for obtaining the data of national populations [27]. The latest available data were used in this study.

\section{$3 \quad$ Methodology}

Several methods are useful for exploring the critical CWE flows, for example, Material Flow Analysis (MFA) [28] and Life Cycle Assessment (LCA) [29]. Both are useful tools for quantifying environmental impacts. However, each tool has drawbacks, for example, the supply chain assessment function of MFA is comparatively partial, and it is difficult for MFA to be used document the environmental influences within the multi-sectors and multiregional systems [30]. Regarding LCA, exploring the WEC flow's characteristics and identifying the specific linkages among different regions or sectors are big challenges [31]. Multi-Criteria analysis is a useful tool for analysing similar issues [32], but it doesn't have the same quantitative level as MRIO. The MRIO highly depends on big sets of systematic and consistent data, which is usually slightly lagging. However, it is a widely used and effective method with good robustness for handling economic and environmental data from the supply chain perspective [18].

\subsection{Multi-Regional Input-Output}

The 2014 MRIO database was the latest one available for the 28 economies, including the EU27 countries and the rest of the world, was analysed. (Format as shown by Table 1). 
The MRIO model was developed based on the World Input-Output Tables (WIOT), which is for $27 \mathrm{EU}$ countries and 16 other major countries/economies [33]. There are 56 economic sectors and five final demand sectors for each economy. In the MRIO table, $z_{i, j}^{r, s}$ indicates the inter-sectoral monetary flow from sector $i$ in economy $r$ to sector $j$ in economy $s . f_{i, k}^{r, s}$ means the final demand of term $k$ in the economy $s$ from sector $i$ in economy $r,(k=1,2,3,4,5$, indicate final consumption expenditures by households, non-profit organisations serving households and government, as well as changes in inventories and valuables and the gross fixed capital formation). $x_{i}^{r}$ is the total output of sector $i$ in economy $r . v_{j}^{s}$ indicates the added value of sector $j$ in economy $s . x_{j}^{s}$ is the total input of sector $j$ in economy $s . e_{j}^{s}$ is the direct energy input of sector $j$ in economy $s . w_{j}^{s}$ is the direct water input of sector $j$ in economy $s$ for both intermediate input and final demand. $c_{j}^{s}$ means the direct $\mathrm{CO}_{2}$ emission from sector $j$ in economy $s$. Each sector of each economy was designated as an individual producer node in the global economy to connect all economic activities of water consumption, energy consumption and $\mathrm{CO}_{2}$ emissions. There are 1,568 nodes in total for 28 economies involved in this study.

Table 1. The format of MRIO table

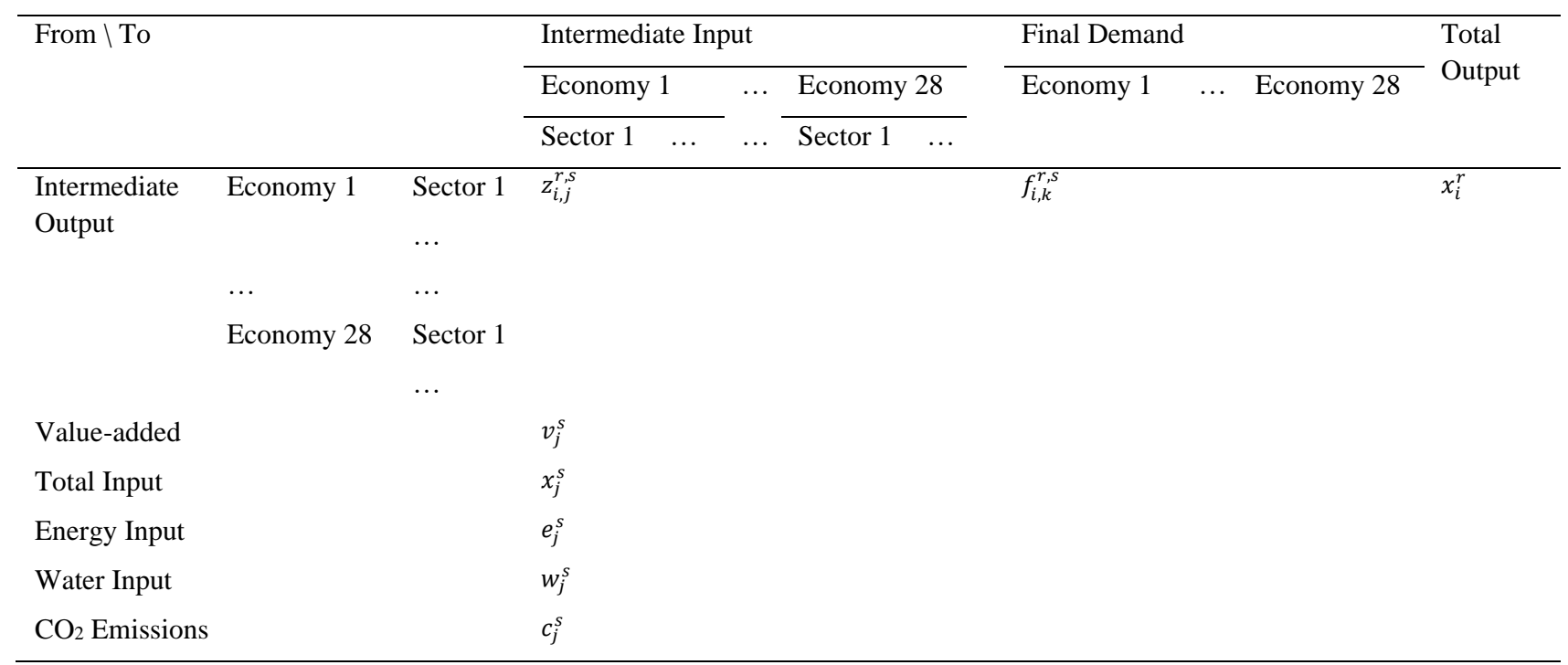

There are two types of balance in the MRIO table: i) The rest of world balance is given by Equation (1); ii) input-output balance as shown by Equations (2), (3) and (4), which represent energy input-output balance, water input-output balance and $\mathrm{CO}_{2}$ emission input-output balance.

$$
x_{i}^{r}=\sum_{s=1}^{28} \sum_{j=1}^{56} z_{i, j}^{r, s}+\sum_{s=1}^{28} f_{i, k}^{r, s},
$$




$$
e_{j}^{s}+\sum_{s=1}^{28} \sum_{j=1}^{56} \varepsilon_{j}^{s} \times z_{j, i}^{r, s}=\varepsilon_{i}^{r} \times\left(\sum_{s=1}^{28} \sum_{j=1}^{56} z_{i, j}^{r, s}+\sum_{s=1}^{28} \sum_{k=1}^{5} f_{i, k}^{r, s}\right)
$$

where $\varepsilon_{j}^{s}$ indicates the embodied energy intensity of sector $j$ in economy $s, z_{j, i}^{r, s}$ indicates the intermediate flow from sector $j$ in economy $r$ to sector $i$ in economy $s, \varepsilon_{i}^{r}$ means the embodied energy intensity of sector $i$ in economy $r$.

$$
w_{j}^{s}+\sum_{s=1}^{28} \sum_{j=1}^{56} \omega_{j}^{s} \times z_{j, i}^{r, s}=\omega_{i}^{r} \times\left(\sum_{s=1}^{28} \sum_{j=1}^{56} z_{i, j}^{r, s}+\sum_{s=1}^{28} \sum_{k=1}^{5} f_{i, k}^{r, s}\right),
$$

where $\omega_{j}^{s}$ is the embodied water intensity of output from sector $j$ in economy $s, z_{j, i}^{r, s}$ indicates the intermediate flow from sector $j$ in economy $r$ to sector $i$ in economy $s, \omega_{i}^{r}$ means the embodied water intensity of output from sector $i$ in economy $r$.

$$
c_{j}^{S}+\sum_{s=1}^{28} \sum_{j=1}^{56} \theta_{j}^{s} \times z_{j, i}^{r, s}=\theta_{i}^{r} \times\left(\sum_{s=1}^{28} \sum_{j=1}^{56} z_{i, j}^{r, s}+\sum_{s=1}^{28} \sum_{k=1}^{5} f_{i, k}^{r, s}\right),
$$

where $\theta_{j}^{s}$ is the embodied $\mathrm{CO}_{2}$ emission intensity of output from sector $j$ in economy $s, z_{j, i}^{r, s}$ indicates the intermediate flow from sector $j$ in economy $r$ to sector $i$ in economy $s, \theta_{i}^{r}$ means the embodied $\mathrm{CO}_{2}$ emission intensity of output from sector $i$ in economy $r$.

The energy-relevant indicators, $\varepsilon_{j}^{s}$ and $\varepsilon_{i}^{r}$, were taken as examples, to show the calculating processes, and introduce the following notations:

$$
\begin{aligned}
& L=\left[\begin{array}{llllll}
\left(\varepsilon_{1}^{1}\right. & \cdots & \varepsilon_{56}^{1}
\end{array}\right) \quad \cdots \quad\left(\begin{array}{lll}
\varepsilon_{1}^{28} & \cdots & \varepsilon_{56}^{28}
\end{array}\right], \\
& E=\left[\begin{array}{lll}
\left(e_{1}^{1}\right. & \cdots & e_{56}^{1}
\end{array}\right) \quad \cdots \quad\left(\begin{array}{lll}
e_{1}^{28} & \cdots & e_{56}^{28}
\end{array}\right],
\end{aligned}
$$

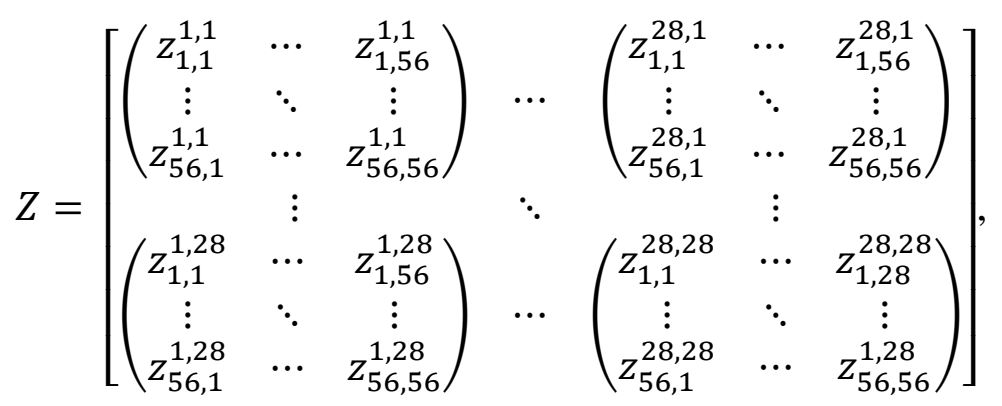

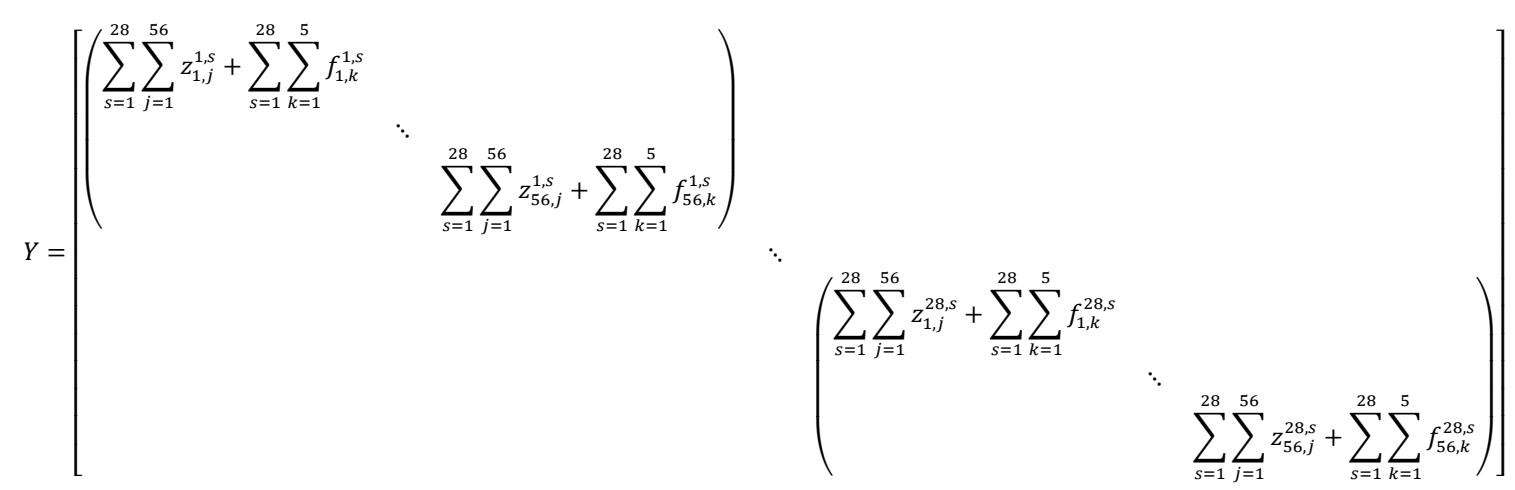

Then the Equation (2) can be transformed into: 


$$
E+L Z=L Y
$$

The $(\mathrm{Y}-\mathrm{Z})$ reversible, then $\mathrm{L}$ can be gained based on Equation (5):

$$
L=\mathrm{E}(\mathrm{Y}-\mathrm{Z})^{-1}
$$

Based on the notation $L$ and Equation (6), we obtained the $\varepsilon_{j}^{s}$ and $\varepsilon_{i}^{r}$.

Then the import embodied energy consumption ( $I E E_{i}^{r}$ ) and export embodied energy consumption $\left(E E E_{i}^{r}\right)$ of sector $i$ in economy $r$ can be given as:

$$
\begin{aligned}
& I E E_{i}^{r}=\sum_{j=1}^{56} \varepsilon_{j}^{s} \times z_{j, i}^{r, s},(r \neq s) \\
& E E E_{i}^{r}=\sum_{j=1}^{56} \varepsilon_{i}^{r} \times z_{i, j}^{r, s},(r \neq s)
\end{aligned}
$$

If both $r$ and $s$ belong to the EU27, then we can obtain the embodied energy consumption of EU27 countries that import from the EU27 members. Otherwise, we obtained the total value of embodied energy consumption that EU27 countries import from the whole world. The proportions can be obtained as well.

Based on Equations (7) and (8), we obtained the import embodied energy consumption (IEE $\left.E^{r}\right)$ and export embodied energy consumption $\left(E E E^{r}\right)$ of economy $r$ :

$$
\begin{aligned}
I E E^{r} & =\sum_{i=1}^{56} I E E_{i}^{r} \\
E E E^{r} & =\sum_{i=1}^{56} E E E_{i}^{r}
\end{aligned}
$$

The net value was given as:

$$
D E E^{r}=I E E^{r}-E E E^{r}
$$

The import embodied water consumption $\left(I W E^{r}\right)$, export embodied water consumption $\left(E W E^{r}\right)$, import/export difference for embodied water $\left(D W E^{r}\right)$, import embodied $\mathrm{CO}_{2}$ emission $\left(I C E^{r}\right)$, export embodied $\mathrm{CO}_{2}$ emission $\left(E C E^{r}\right)$, and the import/export difference for embodied $\mathrm{CO}_{2}$ emissions $\left(D C E^{r}\right)$, of economy $r$ are allocated in the same way.

The coefficients of embodied $\mathrm{CO}_{2}$ emissions, water utilisation and energy consumption were from our previous publication (Table 2), in which the data are consistent with that of this study.

Table 2. Coefficients of embodied $\mathrm{CO}_{2}$ emissions, water utilisation and energy consumption [18]

\begin{tabular}{ll}
\hline EU27 Average & Worldwide Average $\left(A_{W O}\right)$ \\
\hline
\end{tabular}




\begin{tabular}{lcc}
\hline Coefficients of Embodied $\mathrm{CO}_{2}$ Emissions & $A_{E U-C}, 286 \mathrm{t} / \mathrm{M} €$ & $A_{W O-C}, 637 \mathrm{t} / \mathrm{M} €$ \\
Coefficients of Embodied Water Consumption & $A_{E U-E}, 8.8 \mathrm{MJ} / €$ & $A_{W O-E}, 13.9 \mathrm{MJ} / €$ \\
Coefficients of Embodied Energy Consumption & $A_{E U-E}, 27 \mathrm{~m}^{3} / \mathrm{k} €$ & $A_{W O-W}, 75 \mathrm{~m}^{3} / \mathrm{k} €$ \\
\hline
\end{tabular}

Because the EU27 average coefficients are lower than the worldwide average value, we assumed if the same amount of Gross Domestic Product (GDP) is generated, the EU27 can emit less GHG emissions and consume less water and energy. There should be a considerable difference or reduction. Based on the above equations, we obtained the amount of embodied$\mathrm{CO}_{2}$ emissions, -water and -energy that EU27 import from the rest of the world, given as $D_{C}$, $D_{W}$ and $D_{E}$. Then the reduction amounts $\left(R_{C}, R_{W}, R_{E}\right)$ by EU27 can be given as:

$$
\begin{gathered}
R_{C}=D_{C}\left(A_{W O-C} / A_{E U-C}-1\right) \\
R_{W}=D_{W}\left(A_{W O-W} / A_{E U-W}-1\right) \\
R_{E}=D_{E}\left(A_{W O-E} / A_{E U-E}-1\right)
\end{gathered}
$$

\subsection{Sectors Classification Adjustment}

There were 56 very specific sectors, which were not suitable for exploring the embodied consumptions of water and energy as well as the $\mathrm{CO}_{2}$ emissions. These 56 sectors were aggregated into ten big sectors to eliminate this limitation. They included: Agriculture and Forestry (A\&F), Manufacturing (MAN), Mining and Quarrying (M\&Q), Waste Management (WAS), Energy Supply (ENE), Water Management (WAT), Wholesale and retail trade (W\&R), Construction (CON), Transport and Warehousing (T\&W). Social Services (SOC). For more details, see Appendix A1.

\section{$4 \quad$ Results}

\subsection{Regional Patterns of EU27 CWE Nexus}

The authors quantified the embodied $\mathrm{CO}_{2}$ emissions chain (Fig. 1), water chain (Fig. 2) and energy chain (Fig. 3) among the EU27 countries to illustrate the CWE nexus. The $\mathrm{CO}_{2}$ emissions chain of the embodied $\mathrm{CO}_{2}$ emissions flows among the EU27 countries during interregional trade was defined. Similarly, the water chain as the embodied water flows and the energy chain as the embodied energy flows were quantified. The net value of the embodied $\mathrm{CO}_{2}$ flows revealed the widely varied roles; different countries play in international trade. 
Negative means that the country exported more embodied $\mathrm{CO}_{2}$ and positive indicates that the country imported more embodied $\mathrm{CO}_{2}$ than it exported.

The countries with negative values of embodied $\mathrm{CO}_{2}$ emissions imports were non-beneficiaries in this $\mathrm{CO}_{2}$ emissions chain of EU27 interregional trade (Fig. 1), for example, Spain, Ireland, Poland, Romania, Bulgaria, Slovenia, the Czech Republic, Estonia and Lithuania, whereas countries with positive embodied $\mathrm{CO}_{2}$ values were beneficiaries, namely Germany, France, Germany, Italy, Greece, Denmark, Portugal, Sweden, Croatia and Finland. Beneficiaries leave massive embodied $\mathrm{CO}_{2}$ emissions with the non-beneficiaries (i.e. upstream countries) during interregional trade, via importing semi-finished or finished products [18]. Although the upstream countries obtained considerable economic benefits with access to the downstream countries' economies, they bear the consequences of environmental impacts.

Europe emits about 5.06 Gt of embodied $\mathrm{CO}_{2}$ emissions annually. Specifically, the Netherlands had -43.5 Mt, Poland -27.7 Mt, the Czech Republic -10.8 Mt and Belgium -8.6 Mt net outflow values, accounting for $39 \%, 25 \%, 10 \%$ and $8 \%$ separately of the total net embodied $\mathrm{CO}_{2}$ outflows amount in the EU27 countries. The authors documented that these countries are the most upstream economies in the embodied $\mathrm{CO}_{2}$ emissions chain of EU27, bearing most in terms of embodied $\mathrm{CO}_{2}$ emissions and suffer the highest environmental impacts transferred from the downstream countries.

In contrast, France, Germany and Italy have the highest net inflows values, which were $38 \mathrm{Mt}$, 31.6 Mt and 13.9 Mt, accounting for 34\%, 28\% and 12\% respectively, of the total net import amount in the EU27. These beneficiaries transferred most embodied $\mathrm{CO}_{2}$ emissions to the upstream countries and benefited most from the EU27 interregional trade from an embodied $\mathrm{CO}_{2}$ emissions chain perspective. The $\mathrm{CO}_{2}$ emissions chain is mainly driven by the demand of downstream countries, where France, Germany and Italy are the dominant consumers.

The top embodied $\mathrm{CO}_{2}$ emissions flows in the EU27 are from Germany, France and Italy. As the largest trading partner of Germany in the EU27, the Netherlands exported most to Germany in $2014,1.2 \times 10^{11} €$ or $160 \mathrm{Mt}$ in products quantity [34]. This was the biggest embodied $\mathrm{CO}_{2}$ emissions flow, 39.4 Mt, from the Netherlands to Germany, followed by 24.3 Mt from Germany to France, 22.9 Mt from Poland to Germany, 19.3 Mt from Belgium to Germany and 17.7 Mt from Germany to Italy. Germany, France and Italy are the top three countries in the EU27 in terms of economy size [35]. Since Germany, France and Italy have lower $\mathrm{CO}_{2}$ emissions per 
gross domestic product (GDP) [18], they have good potential to decrease their emissions from a global perspective.

Europe uses about $243 \mathrm{Gm}^{3}$ of water annually in economic activity [36]. Agriculture accounts for the largest amount of water consumption at 50\% with energy production using a further 28 $\%$ of water annually [37]. The Netherlands has the most net outflow value in the water chain of EU27 (Fig. 2), which is $-3,502 \mathrm{Mm}^{3}$, followed by Italy at $-2,717 \mathrm{Mm}^{3}$. The Netherlands and Italy account for $63 \%$ of total net outflow amount within the EU27, which is much more than the total amount of all other EU27 countries. These two countries are at the upstream position and serve as water suppliers in the water chain of the EU27.

Comparatively, Germany and France have the highest net import flow values in the water supply chain, which are 4,127 $\mathrm{Mm}^{3}$ and 2,931 $\mathrm{Mm}^{3}$, which accounts for $42 \%$ and $30 \%$ of the total amount within the EU27. They are downstream in the water chain of the EU27 and benefit most in terms of embodied water from interregional trade. The key driver of the water chain is the demand of the downstream countries, where Germany, France and Italy are the dominant consumers. The top embodied water flows within the EU27 are within Germany, France and Italy. The biggest embodied water flow is from the Netherlands to Germany, 3,045 $\mathrm{Mm}^{3}$, which is because of the large amount of trade from the Netherlands to Germany [34], followed by $2,036 \mathrm{Mm}^{3}$ from Italy to Germany, $1,752 \mathrm{Mm}^{3}$ from Italy to France.

Although, Italy exports a large amount of embodied water to Germany and France, it imports massive amounts from other EU27 countries, such as from Germany $\left(1,086 \mathrm{Mm}^{3}\right)$, France $(632$ $\mathrm{Mm}^{3}$ ), the Netherlands $\left(564 \mathrm{Mm}^{3}\right)$ and Spain $\left(458 \mathrm{Mm}^{3}\right)$, which contributes to Italy being one of the top countries in terms of trade-related, embodied water share. Since Germany and France have lower water coefficients $\left(\mathrm{m}^{3} / \mathrm{k} €\right)$ [18], the more net embodied water they import, the more opportunity to improve water efficiency from a global perspective. Italy has the opposite of this trend, with higher water coefficient and lower water utilisation efficiency $\left(\mathrm{m}^{3} / \mathrm{k} €\right)[18]$.

The Netherlands leads the list of net embodied energy outflows (Fig. 3), $-3.5 \times 10^{3} \mathrm{PJ}$ in the EU27, which is much higher than the total amount of the other EU27 countries. It serves as the key supplier to Germany $\left(2.5 \times 10^{3} \mathrm{PJ}\right)$, Belgium $\left(7.1 \times 10^{2} \mathrm{PJ}\right)$, France $\left(6.5 \times 10^{2} \mathrm{PJ}\right)$ and Italy $\left(4.8 \times 10^{2} \mathrm{PJ}\right)$, in total account for $86 \%$ of its embodied energy export. This is because the Rotterdam mega-port in the Netherlands, with its large refining and petrochemicals sector and pipeline connections to neighbouring refineries in Belgium and Germany, is the key energy hub of North-West Europe. 
Germany dominates the list of net imported, embodied energy with $2.4 \times 10^{3} \mathrm{PJ}$, followed by France at $1.2 \times 10^{3} \mathrm{PJ}$. These two countries have more than $1 \times 10^{3} \mathrm{PJ}$ net import embodied energy. Germany is the most downstream country in the energy chain of EU27. It is one of two EU27 countries that imports embodied energy from all other E27 countries. The other one is Sweden, however, with a much lower import value of $\left(8.6 \times 10^{3} \mathrm{PJ}\right)$ and net import value (80 $\mathrm{PJ})$. The biggest embodied energy flow is from the Netherlands to Germany, $2.5 \times 10^{3} \mathrm{PJ}$, followed by $8 \times 10^{2} \mathrm{PJ}$ from Germany to France and $7.2 \times 10^{2} \mathrm{PJ}$ from Belgium to Germany. Based on our previous study, Germany, France, and Italy have higher energy efficiencies [18], than other countries of the EU27.

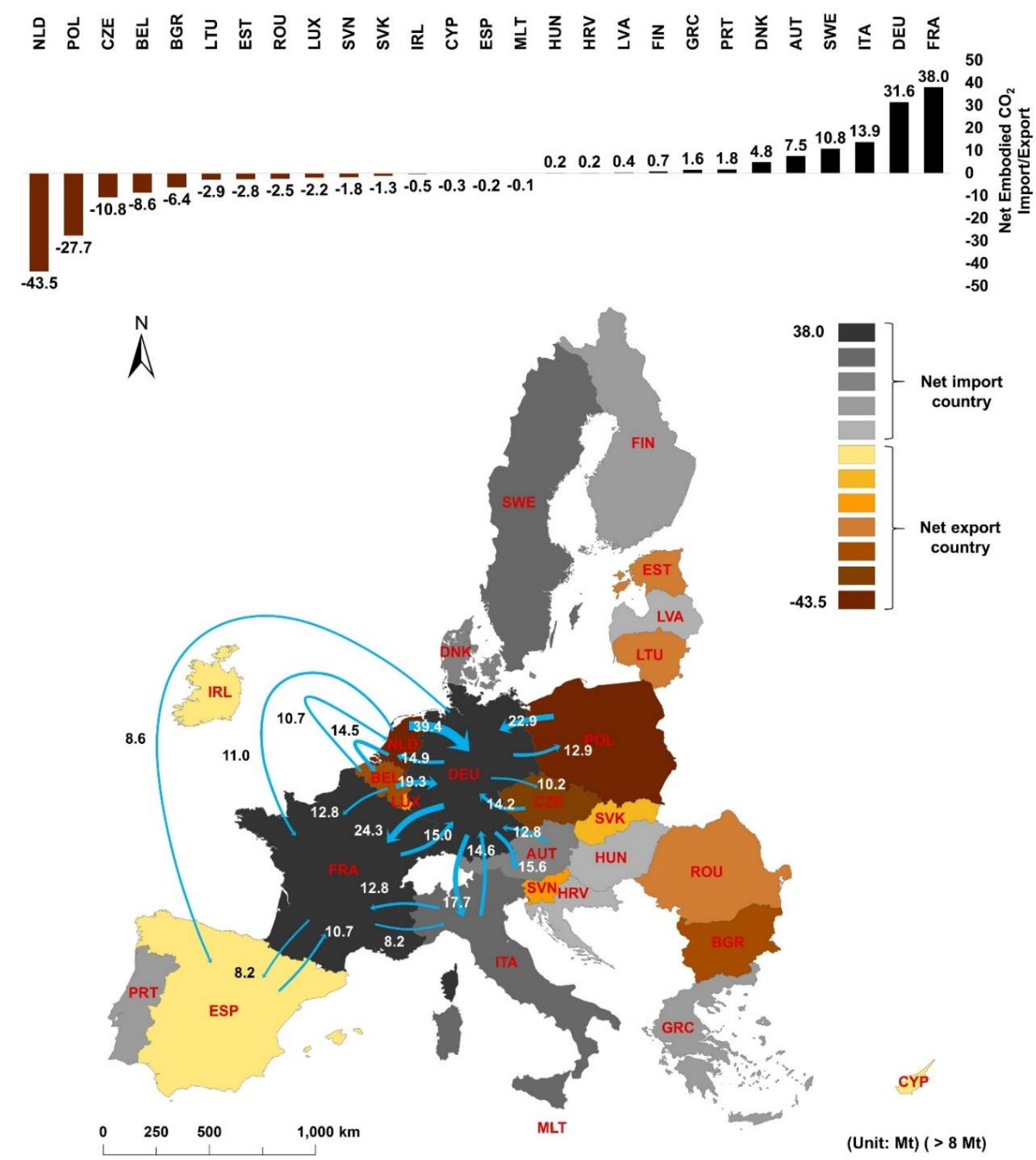


Fig. 1 Embodied $\mathrm{CO}_{2}$ Emissions Chain (> $8 \mathrm{Mt}$ ) of EU27. The width of the arrows reflects the relative magnitudes of the net flows. The colours indicate cities as net exporters (brown) or importers (black). The chains are listed in terms of flows to other countries for amounts greater than $8 \mathrm{Mt} / \mathrm{yr}$.

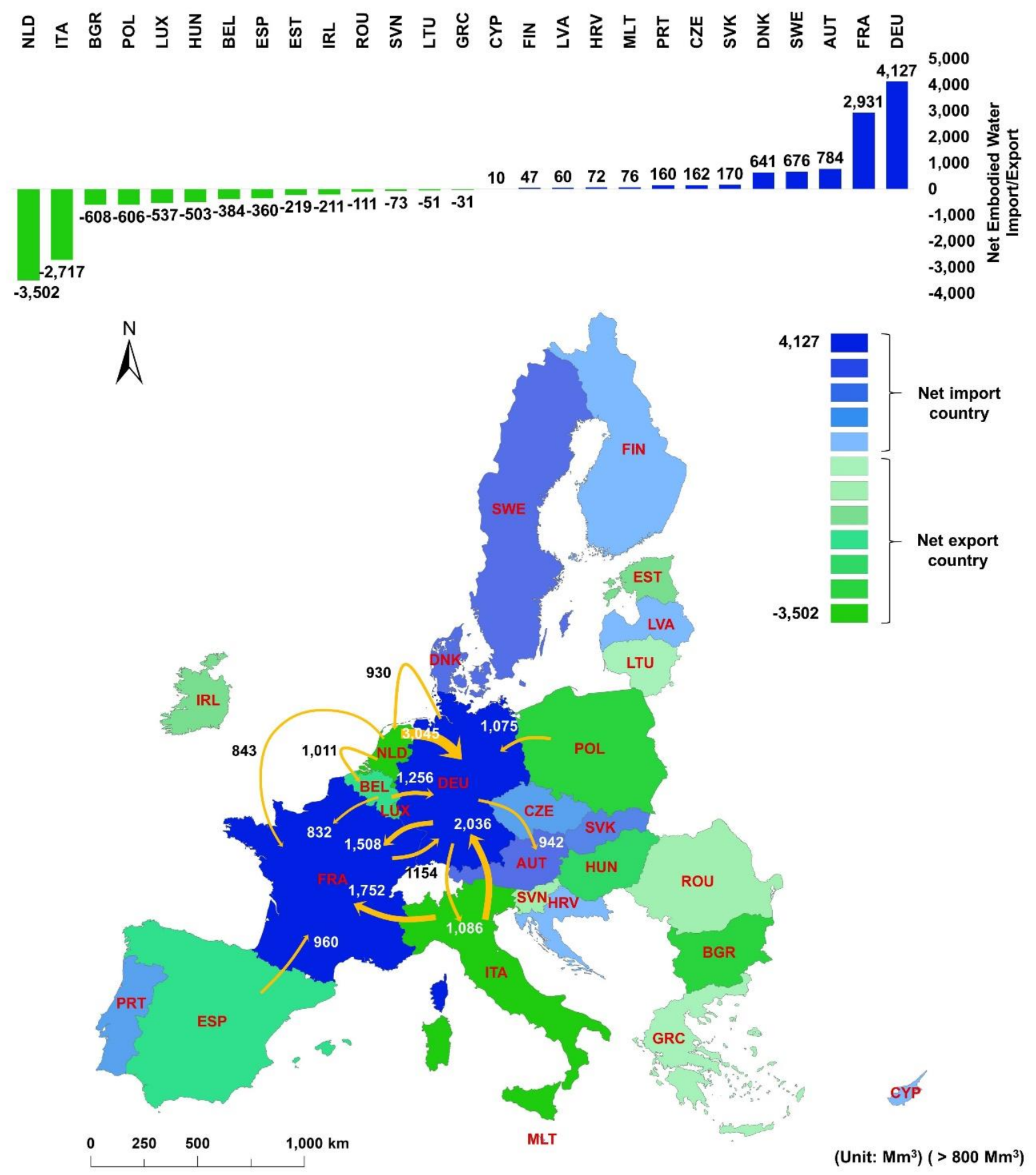

Fig. 2 Embodied Water Chain $\left(>800 \mathrm{Mm}^{3}\right)$ of EU27. The width of the arrows reflects the relative magnitudes of the net flows. The colours indicate cities as net exporters (green) or importers (blue). The chains are listed in terms of flows to other countries with the amount greater than $800 \mathrm{Mm}^{3}$. 

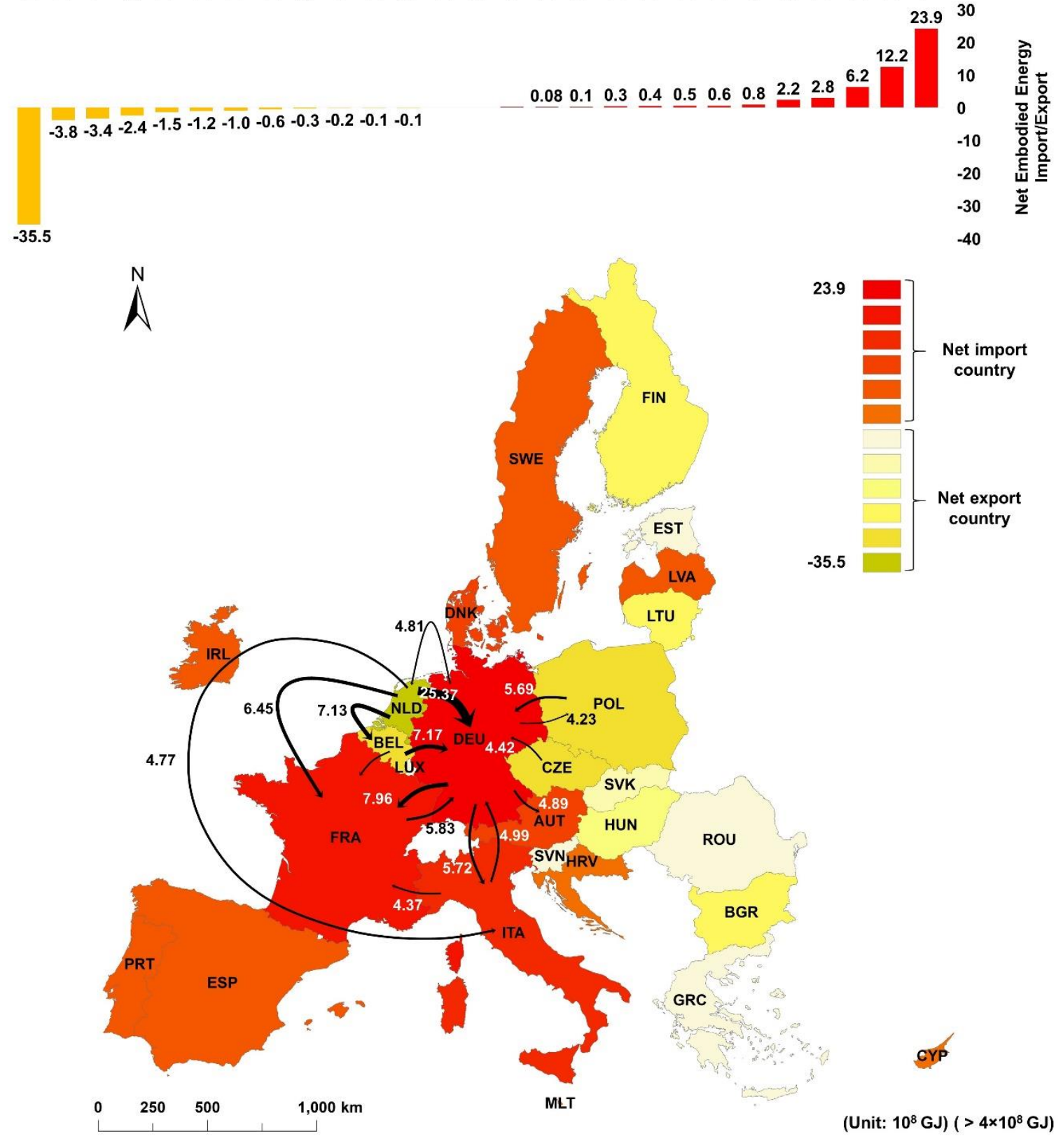

Fig. 3 Embodied Energy Chain $\left(>4 \times 10^{8} \mathrm{GJ}\right)$ of EU27. The width of the arrows reflects the relative magnitudes of the net flows. The colours indicate cities as net exporters (yellow) or importers (red). The chains are listed in terms of flows to other countries, with amounts greater than $4 \times 10^{8} \mathrm{GJ}$.

The interregional trade structure of EU27 directly causes its CWE nexus. The bigger economies usually have larger $\mathrm{CO}_{2}$ emissions, water and energy flows. The structure of the embodied CWE 
import/export (Fig. 4) is roughly consistent with the GDP size of EU27 in 2014 [27]. Germany, France and Italy dominate the lists of embodied CWE imports understandably.

Trade-related, embodied $\mathrm{CO}_{2}$ imported within the EU27 is $736 \mathrm{Mt}$ in total (Fig. 4a). Germany, France and Italy together account for $46 \%$ of that, in which Germany shared $25 \%$, followed by France at $13 \%$ and Italy at $9 \%$. Unlike the import structure, the top embodied $\mathrm{CO}_{2}$ export country is Germany at $151 \mathrm{Mt}$, with $21 \%$ of total export embodied $\mathrm{CO}_{2}$ of EU27, followed by the Netherlands at 89.4 Mt at (12\%), Belgium at 62.1 Mt (8\%) and Poland at 60.4 Mt (8\%). This illustrates why France has the most net value of embodied $\mathrm{CO}_{2}$ import, and the Netherlands is the opposite with a net export of the most embodied $\mathrm{CO}_{2}$ (Fig. 1). The Netherlands is one of the most $\mathrm{CO}_{2}$-intensive (per capita) countries in the EU27 [18]. This is positive because it exports the most embodied $\mathrm{CO}_{2}$ to downstream countries that have higher efficiencies ( $\mathrm{t} / \mathrm{cap}$ ). Trade relevant embodied water demand within EU27 was 52,461 $\mathrm{Mm}^{3}$ in total (Fig. 4b), of which Germany, France and Italy contribute $13,278 \mathrm{Mm}^{3}(25 \%), 7,185 \mathrm{Mm}^{3}$ (14\%) and 4,552 $\mathrm{Mm}^{3}(9 \%)$ respectively. The embodied water demand in these countries represents approximately half of the water demand in the EU27. The Netherlands and Italy have higher net embodied water outflows, and have higher embodied water consumption per capita [18], which means they have lower embodied water flow.

Trade relevant embodied energy imports within EU27 was $2.6 \times 10^{4} \mathrm{PJ}$ in total, of which Germany $\left(7.2 \times 10^{3} \mathrm{PJ}\right)$, France $\left(3.4 \times 10^{3} \mathrm{PJ}\right)$ and Italy $\left(2.4 \times 10^{3} \mathrm{PJ}\right)$ account for $50 \%$. Inversely, Netherlands and Germany export the most embodied energy. But the Netherlands has lower energy efficiency in both monetary units and per capita units [18]. The current situation, with the Netherlands exporting more embodied energy, means it should improve its energy efficiency. 

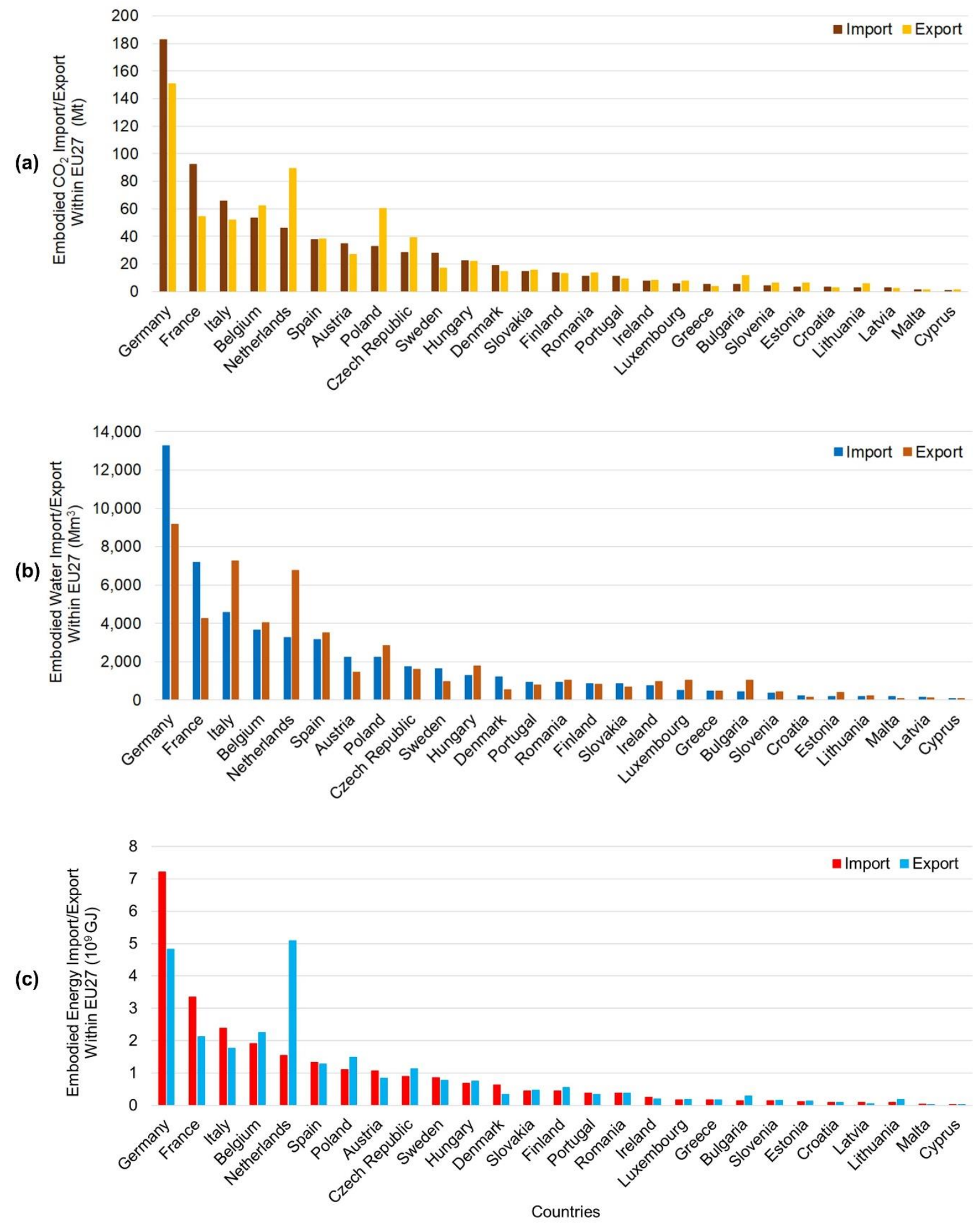

Fig. 4 Embodied CWE Import/Export within the EU27.

\subsection{Sectoral Patterns of EU27 CWE Nexus}

This section presents ten integrated sectors in 2014, including A\&F, M\&Q, MAN, ENE, WAT, WAS, CON, W\&R, T\&W, SOC. 
The $\mathrm{CO}_{2}$ chain within the EU27 is mainly shaped by MAN, SOC and CON sectors (Fig. 5a), accounting for $82 \%$ of the total trade relevant embodied $\mathrm{CO}_{2}$. Manufacturing contributed 451.3 Mt embodied $\mathrm{CO}_{2}$, where $34 \%$ is from the net upstream countries (with net negative values), and the remainder $(66 \%)$ is from downstream countries. This underscores the large impacts of trade among the net downstream countries (with net positive values), although, the net upstream countries supply many resources, they do not benefit much from the commercial chain. The results of other sectors also show the same phenomenon where the SOC sector accounts for 98.5 Mt of trade relevant embodied $\mathrm{CO}_{2}$ flow, with $38 \%$ from net upstream countries and $62 \%$ from net downstream countries. The CON sector's net upstream countries have $35 \%$, and the new downstream countries have $65 \%$, which is a similar structure. All ten sectors showed a similar structure, with a lower share by net upstream countries than by the net downstream countries. The fourth sector, $\mathrm{T} \& \mathrm{~W}$, accounted for $6 \%$ of the total trade-related embodied $\mathrm{CO}_{2}$, followed by W\&R at $5 \%$, ENE at $3 \%$, and in last place WAT at only $0.2 \%$.

Germany was both the biggest supplier and consumer of embodied $\mathrm{CO}_{2}$ from the MAN sector, which accounts for $21 \%$ and $25 \%$ separately, as it is the most industrialised country in the EU27, followed by France and Italy. France contributes $13 \%$ of imported $\mathrm{CO}_{2}$ and $7 \%$ of export $\mathrm{CO}_{2}$ of the EU27. In contrast, the Netherlands contributes $12 \%$ of the total supply; however, they import only $6 \%$ of the total. Poland provides $4.4 \%$ of the import and $8 \%$ of the export, while the Czech Republic provides $3.9 \%$ of the imports and $5 \%$ of the exports of $\mathrm{CO}_{2}$. Comparing global exporter importer $\mathrm{CO}_{2}$ emissions can be examined on a production basis also referred to as territorial emissions or on a 'consumption-based' approach adjusted for emissions. Consumption-based emissions can reflect the consumption and lifestyle choices of a country's citizens [38]. Typically, consumption-based emissions increase when a country becomes richer (e.g. Ireland and the Czech Republic in the 2000s) and production-based emissions remain stationary. Some of the EU27 countries with growing economies (e.g. Latvia, Lithuania, etc.) need to be monitored carefully for this phenomenon, especially when making future $\mathrm{CO}_{2}$ burden-sharing plans. The reverse of this can be seen with positive investment in decarbonisation projects and infrastructure in some of the wealthier industrialised nations, e.g. the UK, France and Germany.

In the EU27's water chain (Fig. 5b), MAN and SOC contribute $84 \%$ of the total trade-related embodied water. Manufacturing contributed 32,091 $\mathrm{Mm}^{3}$, embodied water consumption, where $40 \%\left(12,892 \mathrm{Mm}^{3}\right)$ is from net upstream countries, and the remaining $60 \%\left(19,199 \mathrm{Mm}^{3}\right)$ is from the net downstream countries. The second key sector is SOC, with $7,798 \mathrm{Mm}^{3}$ trade- 
related embodied water, where $45 \%$ is from net upstream countries and $55 \%$ from net downstream countries. For the CON sector, $41 \%$ of trade relevant embodied water is from net upstream countries and the remaining, 59\%, is from downstream countries. In contrast, the WAS and WAT sectors have a higher share from net upstream countries than from net downstream countries, although these two sectors account for only $2 \%$ of the total amount.

In the energy chain (Fig. 5c), the key transmission sector is MAN, contributing $1.7 \times 10^{4} \mathrm{PJ}$ and accounting for $64 \%$, which is much higher than the total amount of the remaining sectors. Of the MAN relevant, $40 \%$ is from net upstream countries, and $60 \%$ is from downstream countries. The key sectors are SOC and CON, accounting for $12 \%$ and $7 \%$ of flows in the energy chain. This indicates that the above three sectors significantly shape the energy supply chain structure in the EU27. 

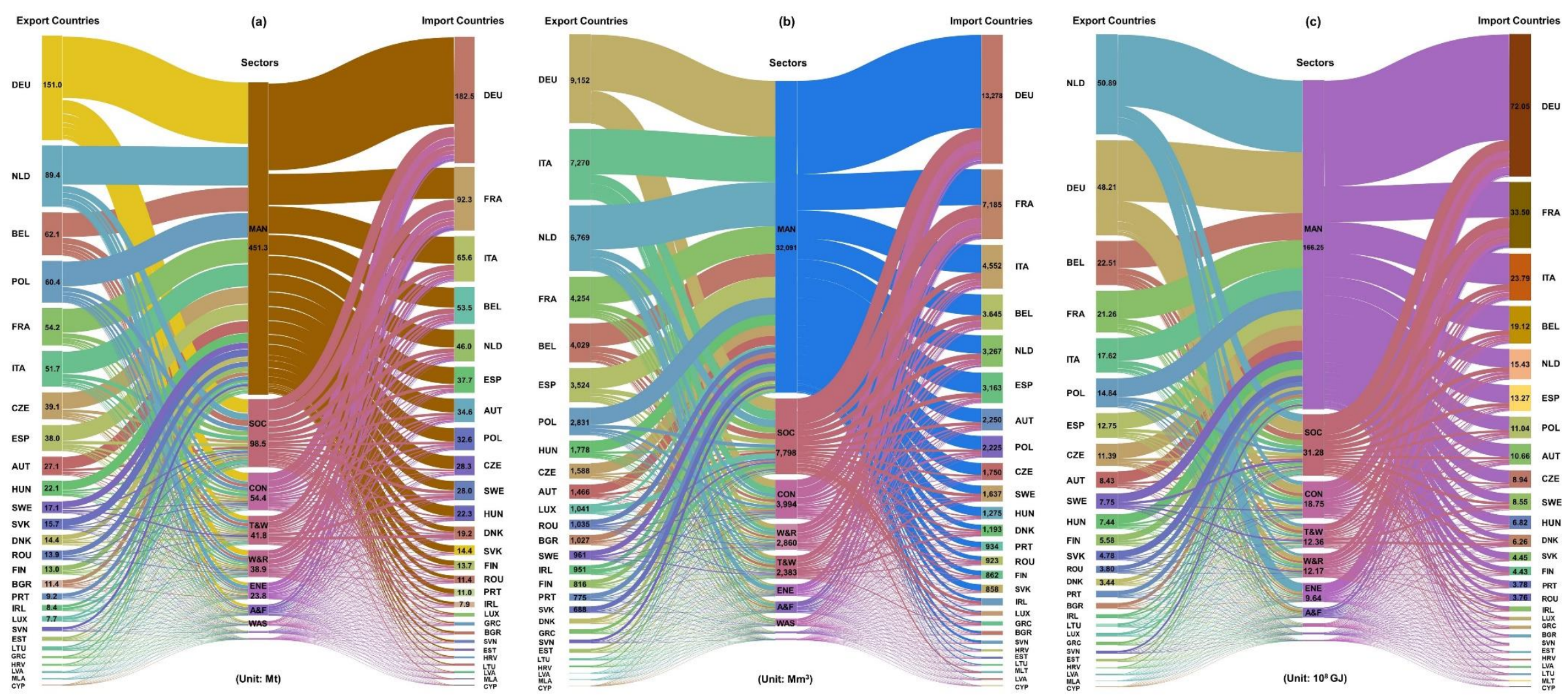

Fig. 5 CWE Chain in Sector Level of EU27.

Agriculture and Forestry (A\&F), Water Management (WAT), Mining and Quarrying (M\&Q), Energy Supply (ENE), Manufacturing (MAN), Social Services (SOC), Waste Management (WAS), Wholesale and Retail Trade (W\&R), Construction (CON), Transport and Warehousing $(\mathrm{T} \& \mathrm{~W})$. 


\subsection{Global Patterns of EU27 CWE Nexus}

EU27 imported significant resources from the whole world in 2014, including CWE. Quantification of the global patterns of EU27 CWE nexus (Fig. 6) is crucial for understanding the impacts of international trade of EU27 on the whole world in terms of climate change, water scarcity and energy consumption.

The EU27 countries transferred 39\% of embodied $\mathrm{CO}_{2}$ within the EU27 (Fig. 6a) while it imported $61 \%$ from the rest of the world. It was assumed in this analysis that if the same amount of GDP is generated, the EU27 could emit $1.4 \mathrm{Gt}$ less $\mathrm{CO}_{2}$ than the rest of the world. Austria has the highest proportion of embodied $\mathrm{CO}_{2}$ imported from EU27, which is $35 \mathrm{Mt}$ and accounts for $59 \%$ of its total imported amount, followed by Hungary at 55\% (22 Mt), the Czech Republic at $54 \%(28 \mathrm{Mt})$, Estonia at 53\% (3Mt) and Slovakia at 51\% (14 Mt). They were the only countries that imported more embodied $\mathrm{CO}_{2}$ from the EU27 than from the rest of the world in 2014.

In contrast, all other $22 \mathrm{EU} 27$ countries imported more embodied $\mathrm{CO}_{2}$ from the rest of the world than from the EU27. Ireland imported $85 \%$ embodied $\mathrm{CO}_{2}$ from non-EU27 countries, namely the UK, the USA, Switzerland and China [39], Greece imports 78\% of trade-related embodied $\mathrm{CO}_{2}$ from non-EU27 such as Iraq, China, and Turkey [40]. Countries with large economies, like Germany, France, Italy and Spain, also imported more from non-EU27 countries than from EU27. Germany imports most embodied $\mathrm{CO}_{2}$ from the rest of the world, which is $227 \mathrm{Mt}$, followed by France at $152 \mathrm{Mt}$, Italy at $118 \mathrm{Mt}$, the Netherlands at $110 \mathrm{Mt}$ and Belgium at 109 Mt. These five countries account for $62 \%$ of that EU27 imported from the rest of the world. The EU27 accounted 15\% of global trade in goods in 2019 [41], and the top 5 imported products were crude petroleum and natural gas (13\% of the total import of EU27), computer, electronic and optical products (13\%), chemicals \& chemical products (7\%), machinery, equipment and motor vehicles, trailers and semi-trailers (both 6\%) [42].

Approximately $32 \%$ of the imported embodied water of EU27 countries is from the EU27 (Fig. $6 \mathrm{~b})$. The remaining $68 \%$ is from the rest of the world, which was $111 \mathrm{Gm}^{3}$. If the same amount of GDP generated was assumed, then the EU27 could consume $64.5 \mathrm{Gm}^{3}$ less water than the rest of the world. Austria is the only country of EU27 that imported less embodied water from the rest of the world than from the EU27 countries. In contrast, the other 26 EU27 countries imported more from the rest of the world than from the EU27. More than 91\% of Ireland's trade-related water imports are from non-EU27 countries, which is because of the nature of the products it imports (e.g. pharmaceuticals, medical devices, integrated circuits and planes). 
Significant quantities of products are virtually imported from the rest of the world-followed by Luxembourg (88\%), Lithuania (78\%) and the Netherlands (78\%). Countries with big economies, like Germany, France, Italy, the Netherlands, Spain, and Belgium, imported more embodied water from the rest of the than from the EU27. Germany, imported the most embodied water from the rest of the world, which was $22,257 \mathrm{Mm}^{3}$, followed by France at $14,647 \mathrm{Mm}^{3}$, the Netherlands at $11,513 \mathrm{Mm}^{3}$ and Italy at $10,320 \mathrm{Mm}^{3}$, accounted for $53 \%$ of what the EU27 imported from the rest of the world.

For EU27 countries, 49\% of imported embodied energy is from the EU27 (Fig. 6c). The remaining $52 \%$ was from the rest of the world, which was $2.8 \times 10^{4} \mathrm{PJ}$. If the same amount of GDP generated is assumed, then the EU27 will consume 49 EJ less energy than the rest of the world, because of the higher energy efficiency $(\mathrm{J} / €)$ of EU27 based on our previous results [18]. Thirteen EU27 countries imported more embodied energy from the EU27 than from the rest of the world (e.g. Austria to Croatia), mainly due to lack of infrastructure and historical links to neighbours. The other 14 countries imported more from the rest of the world than from the EU27. 66\% $\left(1.1 \times 10^{3} \mathrm{PJ}\right)$ of imported embodied energy of Austria is from the EU27 countries, the rest $34 \%$ is from the rest of world, followed by the Czech Republic at $61 \%\left(8.9 \times 10^{2} \mathrm{PJ}\right)$ and Hungary at $60 \%\left(1.1 \times 10^{2} \mathrm{PJ}\right)$.

In contrast, Ireland only imported $19 \%$ of its embodied energy from the EU27 countries but imported $81 \%$ from the rest of the world because of the trade with the UK, USA and China [39]. Greece is in second place, with $71 \%$ imported from the rest of the world, that was primarily refined petroleum [40]. Even when Germany imports more from the EU27, it also imports much from the rest of the world, which was $5.6 \times 10^{3} \mathrm{PJ}$, followed by France at $3.7 \times 10^{3} \mathrm{PJ}$ and Italy at $2.3 \times 10^{3} \mathrm{PJ}$. These three countries dominate the structure of the EU27 energy chain. 


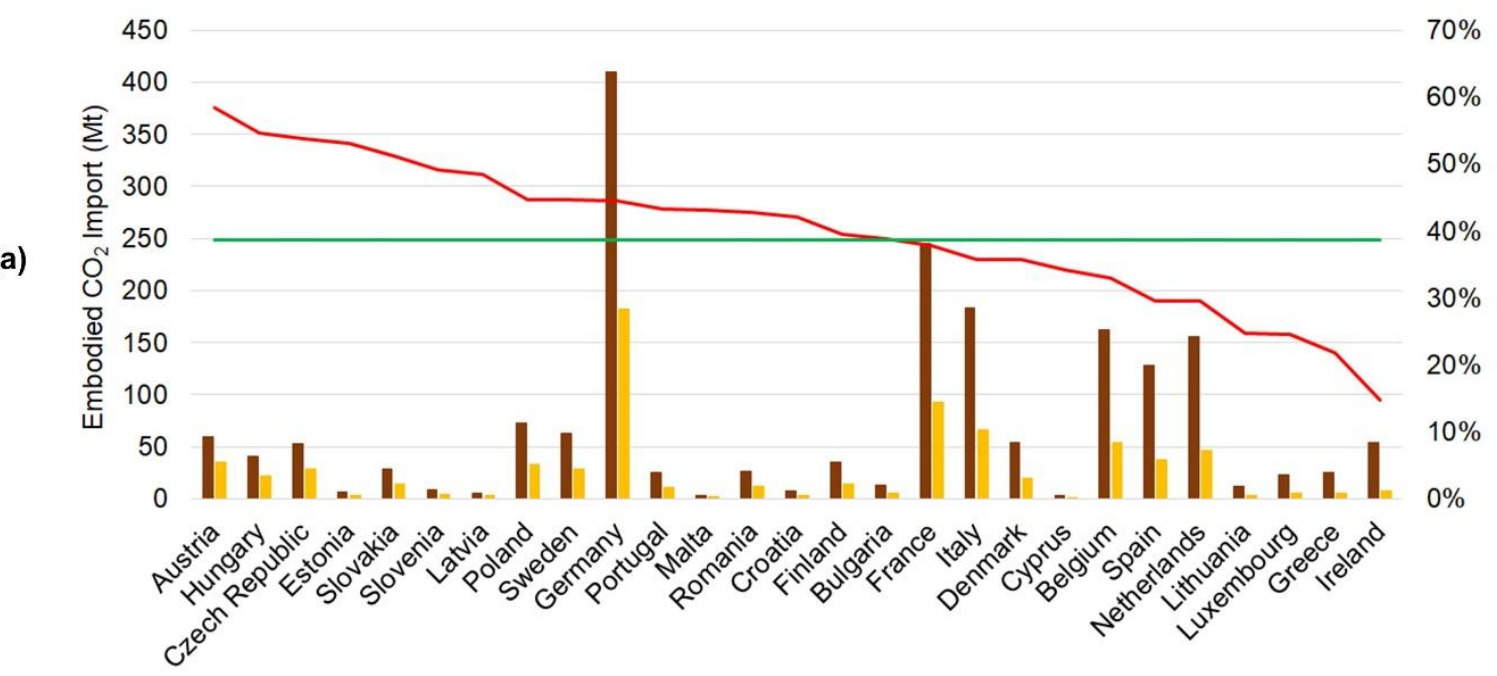

- Import from the whole world Import from the EU27 —Percentage of each country —Percentage of the EU27

40,000

$60 \%$

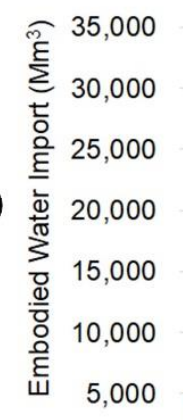

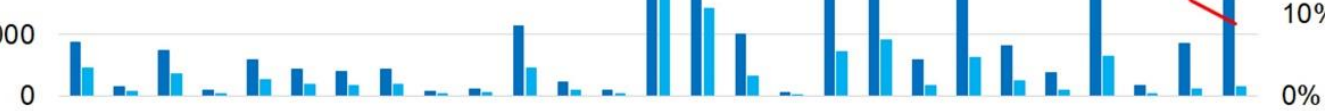

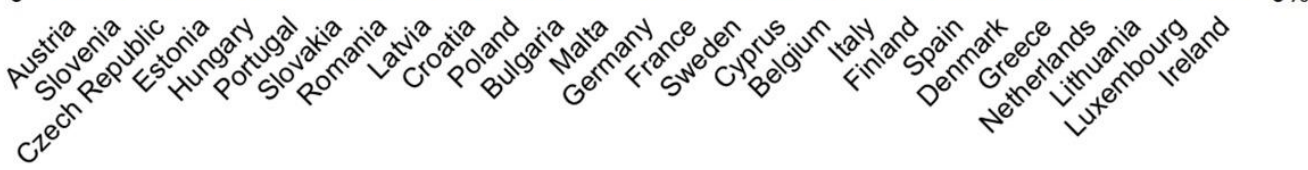

EImport from the whole world $=$ Import from the EU27 —Percentage of each country —Percentage of the EU27

(c)
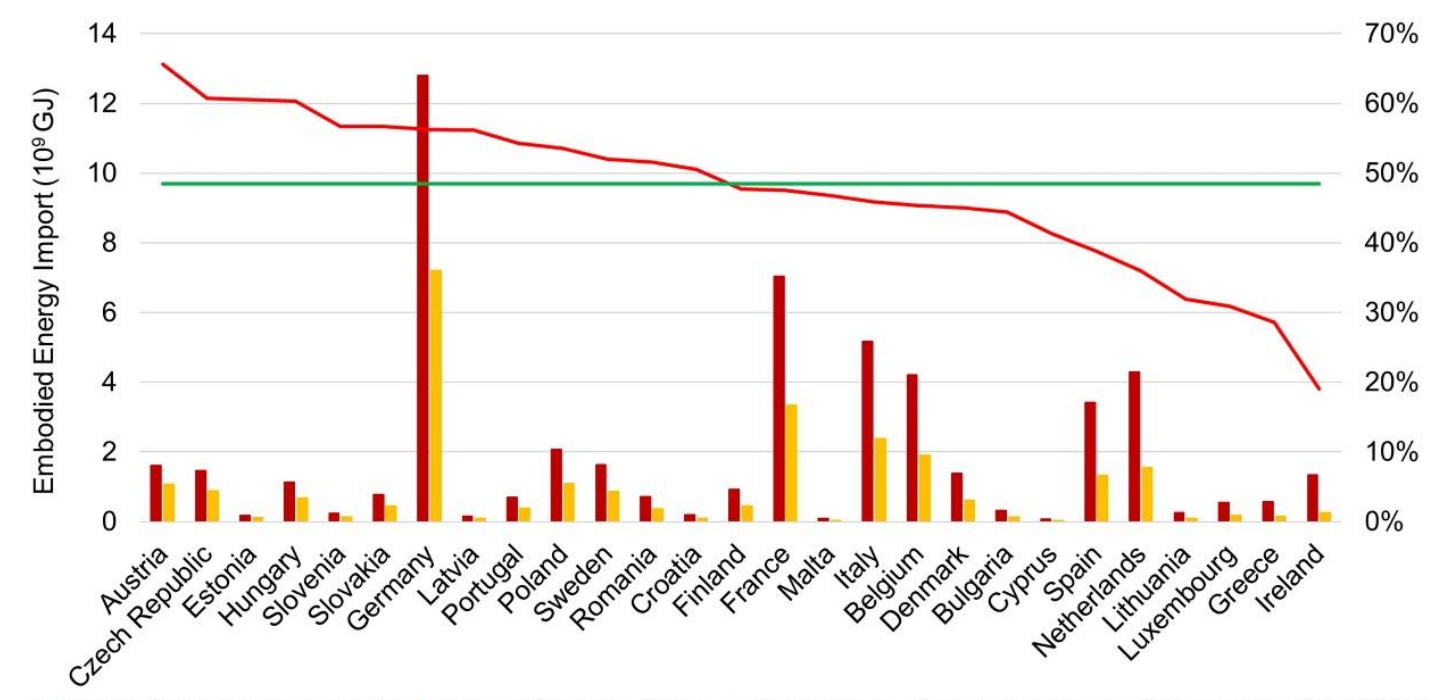

EImport from the whole world $=$ Import from the EU27 —Percentage of each country —Percentage of the EU27 
Fig. 6 Importation Sources Distribution of Embodied-CO 2 (a), -Water (b), -Energy (c) of EU27. Import from the world: the total amount of embodied resource imports of a specific country; Import from the EU27: the total amount of embodied resources that were imported from the EU27 countries; Percentage of each country: the ratio of "import from the EU27" to "import from the world"; the percentage of the EU27: the ratio of the total import of EU27 countries from EU27 to the total import of EU27 countries from the whole world.

\section{$5 \quad$ Discussions and Implications}

Reducing $\mathrm{CO}_{2}$ emissions, and improving water and energy efficiency are key drivers for making progress in transitioning to more environmentally conscious and sustainable economies in line with the SDGs at local, regional and global levels. Unfortunately, the CWE chain in the EU27 is imbalanced and inequitable, and the disparities in CWE flows across the EU27 are significant. Although the population, economy size and GDP of different EU27 countries are very different, there are clear contrasts in the efficiencies of $\mathrm{CO}_{2}$ emissions, water utilisation and energy consumption of the EU27 countries [7] related to products and goods they produce and consume.

Germany and France have lower embodied $\mathrm{CO}_{2}$ emissions, embodied water utilisation and embodied energy consumption per unit GDP [18]. Even if both of them are the top net import countries in terms of embodied CWE, their higher efficiencies are beneficial when making plans to reduce emissions, water and energy utilisations, from a global perspective.

Italy has lower embodied $\mathrm{CO}_{2}$ and energy consumption; however, they have higher water consumption per unit of GDP. Italy is the second-largest, net embodied water supplier, instead of the importer, and one of the top net demanders of embodied $\mathrm{CO}_{2}$ and embodied energy.

The Netherlands has lower efficiency of embodied water and energy and serves as the largest supplier of embodied water and energy, which is good because it transfers embodied resources to downstream countries with higher efficiency. For net upstream countries like the Netherlands, they should focus on improving their domestic efficiency by reducing $\mathrm{CO}_{2}$ emissions, water utilisation and energy consumption.

The effect of lower coefficients and higher efficiencies in the EU27 than the rest of the world based on our previous study [18] showed that the more the EU27 import from the rest of the world, the better for reducing $\mathrm{CO}_{2}$, water and energy consumption in the EU27 while generating the same amount of economic output. The upstream countries would be more affected with 
stricter emissions and energy obligations in the 2030 climate and energy framework as the EU27 move to a climate-neutral economy [43]. This could be distributed by the burden sharing, emissions trading scheme (ETS) and fines. The ETS, a major pillar of the EU energy strategy, was launched for fighting global warming. The EUs ETS is positively contributing to managing the energy and emissions relevant sectors, like the electricity sector [44]. Based on our results, policymakers of the European Commission (EC) and the EU27 Member States are recommended to consider net embodied emissions to allocate burden-sharing.

In the meantime, incentives should be issued for various sectors to make innovations, find alternative renewables, and reduce emissions to ultimately achieve net-zero emission economies by 2050 . Theoretically, taxing the imported $\mathrm{CO}_{2}$ and outsourcing of emissions and consumption-based metrics can be effective ways for the EU to mitigate the impacts of $\mathrm{CO}_{2}$ import; however, the unilateral acts of the EU might result in poorer performance of the politically sensitive sectors, like chemicals, iron and steel industry, fossil-fuel industry [45].

In essence, the only way to achieve this is by improving efficiency. However, this can only be done by increased resources and regulations like those in the EU27. The issue is that this will require investments, and may result in increases in costs from supplier countries. Traditionally, pushing manufacturing to a poorer, less developed economy had been the strategy. Then the CWE virtual merry-go-round will begin again. How can this cycle be broken?

For energy utilisation targets of EU from 2021 to 2030, renewable energy shares would achieve at least $32 \%$, and energy efficiency would be improved by at least 33\%. Those targets will help to mitigate global warming and energy crises. In planning for future energy flows and energy security in Europe, the EU27 countries are looking to 'sector coupling' with the electrification of transport and heating and cooling loads. This would help to enable deeper decarbonisation if done correctly using smart technologies and electric transport systems in tandem with renewable energy, and thereby also creating new manufacturing jobs across the EU27 [46].

The big question for the EU27's strongest economies, Germany, France and Italy is, will they import from outside the EU27 block or will they strike a balance with the other Member States to achieve harmony in the CWE nexus?

The EC just announced a drive for offshore wind power to supply its electricity needs; for example, Ireland alone could supply up to $5 \%$ of the EU27 electricity needs [47]. Similarly, countries along southern latitudes of the EU such as Spain, Portugal, Italy and Greece could supply solar photovoltaic energy. The countries that strive to develop green batteries in the 
EU27 need wider economic support from the EU27, instead of only financing for the infrastructure to build wind and solar PV farms. With the European Green Deal [48] roadmap to make the EU27 the first climate-neutral continent by 2050, such opportunities should be embraced, especially with current, low lending cost and the economic impacts of the COVID19 pandemic.

Key challenges for the EC and the EU27 member states are balancing the conflicting stakeholder interests, the low price of fossil fuels and the significant infrastructure and regulatory gaps at the distribution level. However, there has never been a better time to break the fossil fuel addiction across the EU27, which will have significant positive impacts on the global economy, the environment and human health.

The challenge for water management is to make more reasonable and effective strategies with specific goals. The main objective of EU water policies is to ensure water quality standards across the EU27 [49]. There are relevant actions and policies to mitigate water scarcity, to ensure the sustainability of the water systems and to improve water savings and efficiencies, such as launching the Blueprint to Safeguard Europe's Water Resources [50] and updating the "peer-to-peer process support for the improvement of Water Framework Directive and Floods Directive implementation" [51].

However, there are large gaps in the water policies; for example, the water aspect was overlooked for the EU27 in terms of Germany, France and Italy with limited water for their industrial activities [52]. More polluting activities might be transferred to upstream EU countries or elsewhere, as they need massive embodied water to support their industrial development. This needs urgent attention because water is a resource that Germany, France and Italy cannot import from further afield than its neighbours. Agriculturally, water-intensive EU27 countries in Southern and Eastern Europe are expected to suffer more hardships with increasing extreme weather events and higher summer temperatures associated with global warming. In new water policy plans, the EC must consider this for the EU27 so that the food baskets of Europe are not penalised by the more industrially intensive countries.

In the future, this 'breadbasket' characterisation of certain EU27 Member States such as Spain, Italy and Irelands needs to be reflected in the Common Agricultural Policy (CAP) agreements and $\mathrm{CO}_{2}$ emissions burden sharing, reduction targets and fines. Water will become an even more valuable commodity in the future, especially in the more industrialised nations. 
With the COVID-19 pandemic, the situation and the relations have become more complicated, and this demands close observation step-by-step, as $\mathrm{CO}_{2}$ emissions have been embodied en masse in Personal Protective Equipment (PPE) [53] and also with the uncertain development in the energy consumption [54].

This pandemic has already interrupted the regional, interregional and global interdependencies and relationships as the economic, environmental and social impacts. This needs further consideration and will form the follow-up work of this team of researchers.

\section{Conclusions}

With rapid globalisation, regional sustainability should be considered from the global and multisector level, instead of only on a regional single-sector basis, especially in terms of climate change, and the CWE trilemma. This research quantified the CWE flows of EU27 from three angles: regional patterns, sectoral patterns and global patterns. The exploration revealed apparent disparities among different countries within EU27, different sectors, as well in the EU27 as a block of nations compared and with the rest of the world.

Germany, France and Italy are the largest beneficiaries of embodied CWE, accounting for 46 $\%$ of imported embodied $\mathrm{CO}_{2}, 48 \%$ of imported embodied water and $50 \%$ of imported embodied energy in the EU27. In contrast, the Netherlands is the largest supplier of these resources. However, considering the higher efficiency of Germany and France, the current structure is beneficial for reducing emissions and the consumption of water and energy from a global perspective. All countries should focus on improving domestic efficiency and industrial upgrading.

MAN, SOC and CON share $82 \%$ of the total trade relevant embodied $\mathrm{CO}_{2}, 84 \%$ of the total trade-related to embodied water and $84 \%$ of the total trade-related to embodied energy, as shown in Figure 5. In contrast, the ENE, WAT and A\&F contribute a small part at the sector level, in the EU27 CWE chain, indicating that the products of these sectors are not directly involved in inter-regional trade but are mainly involved in domestic trade. MAN is the most significant driver for shaping the CWE nexus of the EU27. It is also the biggest contributor to embodied CWE and has the maximum potential for reducing both resource consumption and emissions. Especially, for the major participants, like Germany, France, Italy and the Netherlands. The key challenge is how to reduce resource consumption, emissions and environmental impacts while ensuring a healthy economy. The only way to reach this is by 
improving efficiency and adjusting the resource structures, such as increasing the renewable energy share in France.

In the EU27, 51\% of imported embodied energy, $68 \%$ imported embodied water, and $61 \%$ imported embodied $\mathrm{CO}_{2}$ are from the rest of the world. Due to the higher efficiency of the EU27 average than of the rest of the world, it contributes to $1.4 \mathrm{Gt}$ less $\mathrm{CO}_{2}$ emission, $64.5 \mathrm{Gm}^{3}$ less water utilisation and 49 EJ less energy consumption, compared to the same economic value outputs generated by the rest of the world. This indicates that the less industrialised economies in the EU27 should engage in $\mathrm{CO}_{2}$ burden-sharing schemes, emissions and green energy targets and CAP updates of the EU27 Green Deal.

This systematic analysis of the CWE chains in the EU27 is crucial to help them to understand the roles of every country and each sector in the whole system at the local, regional and global levels. This analysis can provide support and direction for future research, education and policymaking in the CWE trilemma.

The CWE nexus should be examined in a holistic approach by the EU27 and other larger trading regions to battle climate change, environmental degradation, species diversity losses and economic inequities. This should be undertaken in tandem with a careful examination of the ten key sectors considering the existing NAFTA, WTO, ASEAN trading pacts so that any targets are implemented equitably on a global scale in line with the UN Sustainable Development Goals.

In conclusion, industry, the banking sector and geopolitical stability should be carefully managed in the rebalancing of the CWE virtual footprint flows as part of a new global system. In the context of the COVID-19 pandemic, political leaders, educators, industrialists and all other citizens, have increased responsibilities to systematically and effectively implement the seventeen Sustainable Development Goals within local, regional, national and global systems that are based upon interdependency and ethical consciousness of mankind for the short and long-term future.

There are also some limitations to this study. The embodied WEC coefficients can be different in different years. The import and export amounts of each region/sector considerably rely on the economic market. The results of one specific year can reflect the situation of the EU27; however, a series of results based on several continuous years would contribute more valuable information and offer stronger support for the decision-makers. The rest of the world was treated as a whole and as the 28th region in this study. However, the other countries have different conditions and have different relationships with the EU27 members. The detailed 
inter-linkages among the EU27 countries other countries should be explored more in-depth explored. These are the targets of our future research.

\section{Acknowledgements}

This study is funded by the EU project "Sustainable Process Integration Laboratory - SPIL", project No. CZ.02.1.01/0.0/0.0/15_003/0000456 funded by EU “CZ Operational Programme Research, Development and Education”, Priority 1: Strengthening capacity for quality research under the collaboration agreement with Fudan University and Beijing Normal University, as well as the National Natural Science Foundation of China (No.71961137009; No.71774032) and Newton Advanced Fellowship from the British Academy and the Newton Fund (NAFR2180103).

\section{Declaration}

Declarations of Interest, Aoife Foley, is a co-author on this paper and as the Editor in Chief of Renewable and Sustainable Energy Reviews she/he was blinded to this paper during the review process, and the paper was independently handled by Paul Leahy.

\section{References}

[1] Chen, S., Tan, Y., Liu, Z., 2019. Direct and embodied energy-water-carbon nexus at an inter-regional scale. Applied Energy, 251, p.113401.

[2] Roe S, Streck C, Obersteiner M, Frank S, Griscom B, Drouet L. Contribution of the Land Sector to a $1.5^{\circ} \mathrm{C}$ World. Nature Climate Change 2019; 9:817-28.

[3] IPCC. Global Warming of $1.5^{\circ} \mathrm{C} 2018$. <https://www.ipcc.ch/sr15/> (accessed April 26, 2020).

[4] Smith CJ, Forster PM, Allen M, Fuglestvedt J, Millar RJ, Rogelj J, et al. Current fossil fuel infrastructure does not yet commit us to $1.5^{\circ} \mathrm{C}$ warming. Nature Communications 2019;10:1-10.

[5] UNFCCC. Paris Agreement 1-25 (UNFCCC, Paris, France, 2015).

[6] Wang X-C, Klemeš JJ, Dong X, Fan W, Xu Z, Wang Y, et al. Air pollution terrain nexus: A review considering energy generation and consumption. Renewable and Sustainable Energy Reviews 2019;105:71-85. 
[7] Ritchie, H., Roser, M. $\mathrm{CO}_{2}$ and Greenhouse Gas Emissions. Published online at OurWorldInData.org. > > >ttps://ourworldindata.org/co2-and-other-greenhouse-gasemissions> (accessed April 26, 2020).

[8] Klemeš JJ, Yee VF, Jiang P, 2020. COVID-19 pandemic facilitating energy transition opportunities, International Journal of Energy Research, 2020, 1-7. DOI: 10.1002/er.6007.

[9] UNFCCC, The Paris Agreement. < https://unfccc.int/process-and-meetings/the-parisagreement/the-paris-agreement > (accessed August 30, 2020).

[10] Kundzewicz ZW, Krysanova V, Benestad RE, Hov Ø, Piniewski M, Otto IM. Uncertainty in climate change impacts on water resources. Environmental Science \& Policy 2018;79:1-8.

[11] Perera ATD, Nik VM, Chen D, Scartezzini J-L, Hong T. Quantifying the impacts of climate change and extreme climate events on energy systems. Nature Energy 2020;5:150-9.

[12] Wiedmann T, Lenzen M. Environmental and social footprints of international trade. Nature Geoscience 2018;11:314-21.

[13] Peters, G.P., Minx, J.C., Weber, C.L., Edenhofer, O., 2011. Growth in emission transfers via international trade from 1990 to 2008. Proceedings of the national academy of sciences, 108(21), 8903-8908.

[14] Duan C, Chen B. Driving factors of water-energy nexus in China. Applied Energy 2020; 257:113984.

[15] Wang X-C, Klemeš JJ, Wang Y, Dong X, Wei H, Xu Z, et al. Water-Energy-Carbon Emissions nexus analysis of China: An environmental input-output model-based approach. Applied Energy 2020; 261:114431.

[16] Khan Z, Linares P, Rutten M, Parkinson S, Johnson N, García-González J. Spatial and temporal synchronisation of water and energy systems: Towards a single integrated optimisation model for long-term resource planning. Applied Energy 2018;210:499-517.

[17] Meng F, Liu G, Liang S, Su M, Yang Z. Critical review of the energy-water-carbon nexus in cities. Energy 2019;171:1017-32.

[18] Wang X-C, Klemeš JJ, Long X, Zhang P, Varbanov PS, Fan W, et al. Measuring the environmental performance of the EU27 from the Water-Energy-Carbon nexus perspective. Journal of Cleaner Production 2020:121832.

[19] Yang X, Yi S, Qu S, Wang R, Wang Y, Xu M. Key transmission sectors of energy-watercarbon nexus pressures in Shanghai, China. Journal of Cleaner Production 2019;225:2735 . 
[20] Wang X-C, Klemeš JJ, Varbanov PS. Water-Energy-Carbon Nexus Analysis of the EU27 and China. Chemical Engineering Transactions 2020;81:469-74.

[21] Niva V, Cai J, Taka M, Kummu M, Varis O. China's sustainable water-energy-food nexus by 2030: Impacts of urbanisation on sectoral water demand. Journal of Cleaner Production 2020; 251:119755.

[22] Hoekstra AY. The Water Footprint of Modern Consumer Society. Routledge, London, UK. 2019.

[23] Corsatea, T.D., Lindner, S., Arto, I., Román, M.V., Rueda-Cantuche, J.M., Velázquez Afonso, A., Amores, A.F., Neuwahl, F. World input-output database environmental accounts: update 2000-2016. 2019. <https://ec.europa.eu/jrc/en/publication/world-inputoutput-database-environmental-accounts> (accessed March 19, 2020).

[24] Timmer MP. An Anatomy of the Global Trade Slowdown based on the WIOD 2016 Release 2016. <www.wiod.org/database/wiots16> (accessed February 19, 2020).

[25] The World Bank. Official exchange rate. <https://data.worldbank.org/indicator/ PA.NUS.FCRF> (accessed October 10, 2020).

[26] Database - Eurostat 2020. <https://ec.europa.eu/eurostat/data/database> (accessed February 19, 2020).

[27] The World Bank. Population 2020. <https://data.worldbank.org/indicator/ SP.POP.TOTL> (accessed February 24, 2020).

[28] Sun X, Hao H, Zhao F, Liu Z. Tracing global lithium flow: A trade-linked material flow analysis. Resources, Conservation and Recycling 2017;124:50-61.

[29] Friedrich J, Poganietz W-R, Lehn H. Life-cycle assessment of system alternatives for the Water-Energy-Waste Nexus in the urban building stock. Resources, Conservation and Recycling 2020;158:104808.

[30] Islam, M.T., Huda, N., 2019. Material flow analysis (MFA) as a strategic tool in E-waste management: Applications, trends and future directions. Journal of environmental management, 244, 344-361.

[31] Islam, K.N., Kenway, S.J., Renouf, M.A., Lam, K.L. and Wiedmann, T., 2020. A review of the water-related energy consumption of the food system in nexus studies. Journal of Cleaner Production, p.123414.

[32] Antanasijević, D., Pocajt, V., Ristić, M., Perić-Grujić, A., 2017. A differential multicriteria analysis for the assessment of sustainability performance of European countries: Beyond country ranking. Journal of cleaner production, 165, 213-220. 
[33] Timmer MP, Dietzenbacher E, Los B, Stehrer R, Vries GJ de. An Illustrated User Guide to the World Input-Output Database: the Case of Global Automotive Production. Review of International Economics 2015;23:575-605.

[34] European Commission. Statistics. Trade Helpdesk 2015. <https://trade.ec.europa.eu/ tradehelp/statistics> (accessed May 5, 2020).

[35] The World Bank. World Development Indicators: Size of the economy. <wdi.worldbank.org/table/WV.1> (accessed October 10, 2020).

[36] European Environment Agency. Water use in Europe - Quantity and quality face big challenges 2018. <https://www.eea.europa.eu/signals/signals-2018-content-list/articles/ water-use-in-europe-2014> (accessed May 5, 2020).

[37] European Environment Agency. Water-use-in-europe 2020. <https://www.eea.europa.eu/ signals/signals-2018-content-list/infographic/water-use-in-europe> (accessed June 1, 2020).

[38] Our World in Data. How do $\mathrm{CO}_{2}$ emissions compare when we adjust for trade? Our World in Data 2019. <https://ourworldindata.org/consumption-based-co2> (accessed June 1, 2020).

[39] OEC - Ireland (IRL) Exports, Imports, and Trade Partners 2020. <https://oec.world/ en/profile/country/irl/\#Imports > (accessed May 7, 2020).

[40] OEC - Greece (GRC) Exports, Imports, and Trade Partners 2020. <https://oec.world/ en/profile/country/grc/> (accessed May 7, 2020).

[41] European Parliament. The EU's position in world trade in figures (infographic) | News | European Parliament 2018. <https://www.europarl.europa.eu/news/en/headlines/ economy/20180703STO07132/the-eu-s-position-in-world-trade-in-figures-infographic> (accessed June 1, 2020).

[42] Eurostat. Main goods in extra-EU imports - Statistics Explained 2020. <https:// ec.europa.eu/eurostat/statistics-explained/index.php/Main_goods_in_extra-EU_imports> (accessed June 1, 2020).

[43] Anonymous. 2030 climate \& energy framework. Climate Action - European Commission 2016. <https://ec.europa.eu/clima/policies/strategies/2030_en> (accessed June 1, 2020).

[44] Kirat, D., Ahamada, I., 2011. The impact of the European Union emission trading scheme on the electricity-generation sector. Energy Economics, 33(5), 995-1003.

[45] Centre for European Reform. Should The EU Tax Imported $\mathrm{CO}_{2}$ ? <https://www.cer.eu/insights/should-eu-tax-imported-co2> (Accessed October 11, 2020) 
[46] Scott M. Electrifying Heat, Transport and Industry Can Lead to Deep Carbon Cuts. Forbes 2020. <https://www.forbes.com/sites/mikescott/2020/02/13/electrifying-heat-transportand-industry-can-lead-to-deep-carbon-cuts/> (accessed June 1, 2020).

[47] Environment KO, Editor S. Ireland ‘could supply 5\% of Europe's electricity’ with offshore wind. The Irish Times 2020. <https://www.irishtimes.com/news/environment/irelandcould-supply-5-of-europe-s-electricity-with-offshore-wind-1.4194310> (accessed June 1, 2020).

[48] European Commission. The European Green Deal 2019. <https://ec.europa.eu/info/ sites/info/files/european-green-deal-communication-annex-roadmap_en.pdf> (accessed July 1, 2020).

[49] European Commission. Water scarcity and drought - Environment - European Commission. <https://ec.europa.eu/environment/water/quantity/scarcity_en.htm> (accessed May 21, 2020).

[50] European Parliament. Water protection and management, Fact Sheets on the European Union. <https://www.europarl.europa.eu/factsheets/en/sheet/74/water-protection-andmanagement $>$ (accessed August 8, 2020).

[51] European Commission. P2P. <https://www.aquacoope.org/peertopeer/en/ > (accessed August 8, 2020).

[52] Blue-Cloud. The EU Blue Economy Report 2020. < https://www.blue-cloud.org/news/eublue-economy-report-2020> (accessed August 8, 2020).

[53] Klemeš JJ, Fan YV, Tan RR, Jiang P. Minimising the present and future plastic waste, energy and environmental footprints related to COVID-19. Renewable and Sustainable Energy Reviews 2020;127:109883.

[54] Klemeš JJ, Fan YV, Jiang P. The Energy and Environmental Footprints of COVID-19 Fighting Measures - PPE, Disinfection, Supply Chains, Energy, 2020, 118701, doi: 10.1016/j.energy.2020.118701. 


\section{Appendices}

Appendices A1. The congruent linkages between original and aggregated sectors.

\begin{tabular}{|c|c|c|}
\hline Abbreviations & Aggregated Sectors & Original Sectors \\
\hline $\mathrm{A} \& \mathrm{~F}$ & Agriculture and Forestry & $\begin{array}{l}\text { Crop and animal production, hunting and related service } \\
\text { activities } \\
\text { Forestry and logging } \\
\text { Fishing and aquaculture }\end{array}$ \\
\hline MAN & Manufacturing & $\begin{array}{l}\text { Manufacture of wood and products of wood and cork, except } \\
\text { furniture; manufacture of articles of straw and plaiting } \\
\text { materials } \\
\text { Manufacture of chemicals and chemical products } \\
\text { Manufacture of rubber and plastic products } \\
\text { Manufacture of paper and paper products } \\
\text { Manufacture of fabricated metal products, except machinery and } \\
\quad \text { equipment } \\
\text { Manufacture of food products, beverages and tobacco products } \\
\text { Manufacture of basic pharmaceutical products and } \\
\text { pharmaceutical preparations } \\
\text { Manufacture of coke and refined petroleum products } \\
\text { Manufacture of electrical equipment } \\
\text { Manufacture of machinery and equipment n.e.c. } \\
\text { Manufacture of textiles, wearing apparel and leather products } \\
\text { Manufacture of basic metals } \\
\text { Manufacture of computer, electronic and optical products } \\
\text { Manufacture of other non-metallic mineral products } \\
\text { Manufacture of motor vehicles, trailers and semi-trailers } \\
\text { Manufacture of other transport equipment } \\
\text { Manufacture of furniture; other manufacturing } \\
\text { Repair and installation of machinery and equipment }\end{array}$ \\
\hline M\&Q & Mining and Quarrying & Mining and quarrying \\
\hline WAS & Waste Management & $\begin{array}{l}\text { Sewerage; waste collection, treatment and disposal activities; } \\
\text { materials recovery; remediation activities and other waste } \\
\text { management services }\end{array}$ \\
\hline ENE & Energy Supply & Electricity, gas, steam and air conditioning supply \\
\hline WAT & Water Management & Water collection, treatment and supply \\
\hline $\mathrm{W} \& \mathrm{R}$ & Wholesale and Retail Trade & $\begin{array}{l}\text { Wholesale and retail trade and repair of motor vehicles and } \\
\text { motorcycles } \\
\text { Wholesale trade, except motor vehicles and motorcycles } \\
\text { Retail trade, except motor vehicles and motorcycles }\end{array}$ \\
\hline $\mathrm{CON}$ & Construction & Construction \\
\hline $\mathrm{T} \& \mathrm{~W}$ & Transport and Warehousing & $\begin{array}{l}\text { Land transport and transport via pipelines } \\
\text { Air transport } \\
\text { Water transport } \\
\text { Warehousing and support activities for transportation }\end{array}$ \\
\hline SOC & Social Services & $\begin{array}{l}\text { Publishing activities } \\
\text { Telecommunications } \\
\text { Printing and reproduction of recorded media } \\
\text { Administrative and support service activities } \\
\text { Public administration and defence; compulsory social security }\end{array}$ \\
\hline
\end{tabular}


Postal and courier activities

Education

Insurance, reinsurance and pension funding, except compulsory social security

Activities auxiliary to financial services and insurance activities

Scientific research and development

Advertising and market research

Other professional, scientific and technical activities; veterinary activities

Legal and accounting activities; activities of head offices; management consultancy activities

Architectural and engineering activities; technical testing and analysis

Accommodation and food service activities

Computer programming, consultancy and related activities; information service activities

Financial service activities, except insurance and pension funding

Real estate activities

Activities of households as employers; undifferentiated goodsand services-producing activities of households for own use

Activities of extraterritorial organisations and bodies

Human health and social work activities

Other service activities 